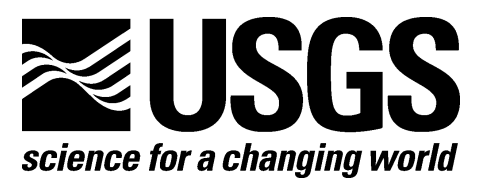

In cooperation with George Mason University

\title{
Summary of Mercury and Trace Element Results in Precipitation from the Culpeper, Virginia, Mercury Deposition Network Site (VA-08), 2002-2006
}

By Mark A. Engle, Allan Kolker, Douglas E. Mose, Joseph A. East, and Jamey D. McCord

Report Series 2008-1232

U.S. Department of the Interior U.S. Geological Survey 


\section{U.S. Department of the Interior DIRK KEMPTHORNE, Secretary}

\section{U.S. Geological Survey \\ Mark D. Myers, Director}

U.S. Geological Survey, Reston, Virginia 2008

For product and ordering information:

World Wide Web: http://www.usgs.gov/pubprod

Telephone: 1-888-ASK-USGS

For more information on the USGS - the Federal source for science about the Earth,

its natural and living resources, natural hazards, and the environment:

World Wide Web: http://www.usgs.gov

Telephone: 1-888-ASK-USGS

Suggested citation:

Engle, M.A., Kolker, A., Mose, D.E., East, J.A., and McCord, J.D., 2008, Summary of Mercury and Trace Element Precipitation Results from the Culpeper, Virginia, Mercury Deposition Network Site (VA-08), 20022006: U.S. Geological Survey Open File Report 2008-1232.

Any use of trade, product, or firm names is for descriptive purposes only and does not imply endorsement by the U.S. Government.

Although this report is in the public domain, permission must be secured from the individual copyright owners to reproduce any copyrighted material contained within this report. 


\section{Contents}

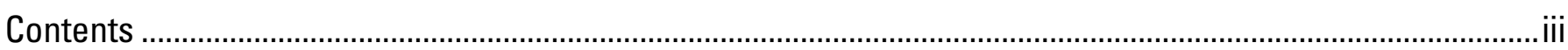

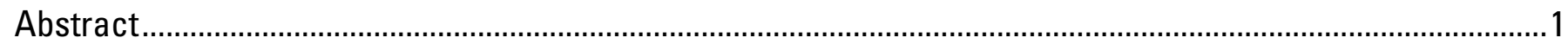

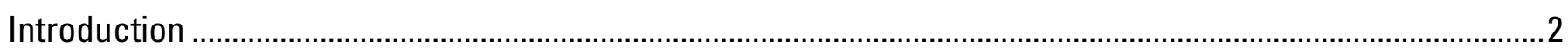

Potential Sources of Mercury in Atmospheric Wet Deposition.....................................................................2

Mechanisms for Trace Element Scavenging in Precipitation ......................................................................

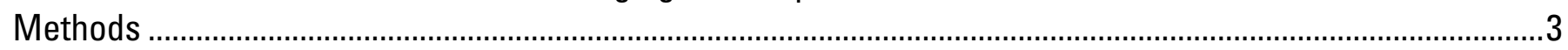

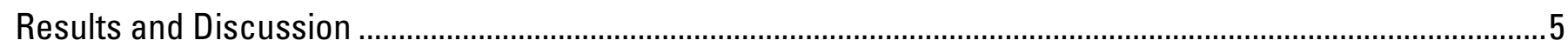

Comparison with the Big Meadows Mercury Deposition Network Site ....................................................6

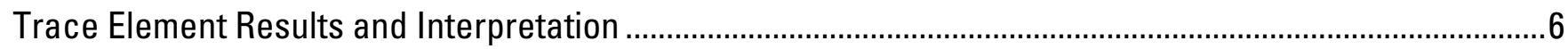

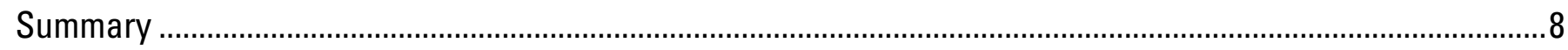

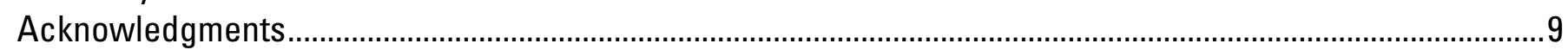

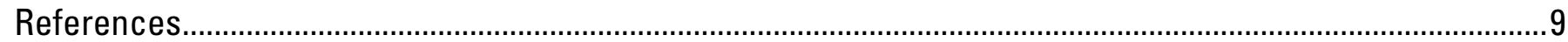




\title{
Summary of Mercury and Trace Element Results in Precipitation from the Culpeper, Virginia, Mercury Deposition Network Site (VA-08), 2002-2006
}

\author{
By Mark A. Engle', Allan Kolker', Douglas E. Mose ${ }^{2}$, Joseph A. East', and Jamey D. McCord ${ }^{3}$
}

\begin{abstract}
The VA-08 Mercury Deposition Network (MDN) site, southwest of Culpeper, Virginia, was established in autumn of 2002. This site, along with nearby VA-28 ( 31 km west) at Big Meadows in Shenandoah National Park, fills a spatial gap in the Mid-Atlantic region of the MDN network and provides $\mathrm{Hg}$ deposition data immediately west of the Washington, D.C., metropolitan area. Results for the Culpeper site from autumn of 2002 to the end of 2006 suggest that the highest mercury $(\mathrm{Hg}$ ) deposition (up to $5.0 \cdot \mathrm{g} / \mathrm{m} 2$ per quarter of the $6.5-12.6 \cdot \mathrm{g} / \mathrm{m} 2$ annual $\mathrm{Hg}$ deposition) is measured during the second and third quarters of the year (April-September). This is a result of both elevated $\mathrm{Hg}$ precipitation concentrations (up to $27 \mathrm{ng} / \mathrm{L}$ ) and greater precipitation during these months. The data also exhibit a general statistically significant $(\mathrm{p}<0.05)$ negative correlation between weekly total precipitation and $\mathrm{Hg}$ concentrations, suggesting a dilution effect during larger precipitation events, especially during winter and spring. Comparison of results between the Culpeper and Big Meadows sites indicates that although quarterly $\mathrm{Hg}$ deposition was not significantly different $(\mathrm{p}<0.05)$ between sites, quarterly volume-averaged $\mathrm{Hg}$ precipitation concentrations were statistically larger $(\mathrm{p}<0.05)$ and precipitation was significantly lower $(\mathrm{p}<0.05)$ at VA-08. Lower Hg concentrations at the VA-28 site relative to VA-08 are likely a result of greater total precipitation and thus additional dilution of $\mathrm{Hg}$ in precipitation.

Results from concomitant trace elements in precipitation collected from July, 2005, to December, 2006, were used to better identify possible sources of $\mathrm{Hg}$ at the Culpeper MDN site. Principal component analysis of the $\mathrm{Hg}$ and trace metal data identified 3 primary source categories, each with large loadings of characteristic elements: 1) $\mathrm{Ca}, \mathrm{Al}, \mathrm{Mg}, \mathrm{Sr}, \mathrm{La}$, and $\mathrm{Ce}$ (crustal sources); 2) $\mathrm{V}, \mathrm{Na}$, and $\mathrm{Ni}$ (local wintertime heating oil); and 3) $\mathrm{Zn}, \mathrm{Cd}, \mathrm{Mn}$, and $\mathrm{Hg}$ (regional anthropogenic emission sources). HYSPLIT air mass trajectory modeling and enrichment factor calculations are consistent with this interpretation. A preliminary source attribution model suggests that $\sim 51 \%$ of the $\mathrm{Hg}$ in wet deposition is due to regional anthropogenic sources, while crustal sources and local oil combustion account for $9.5 \%$ and $<1 \%$, respectively. This calculation implies that the global $\mathrm{Hg}$ burden accounts for $\sim 40 \%$ of the $\mathrm{Hg}$ in wet deposition.
\end{abstract}

\footnotetext{
${ }^{1}$ U.S. Geological Survey. Eastern Energy Resources Team, 956 National Center, Reston, Virginia

${ }^{2}$ Department of Chemistry, George Mason University, Fairfax, Virginia

${ }^{3}$ U.S. Geological Survey, Central Energy Resources Team, Denver Federal Center, MS 973, Denver, Colorado
} 


\section{Introduction}

Wet and dry deposition of mercury $(\mathrm{Hg})$ and other trace elements are important mechanisms for input of these components into ecosystems. This is highlighted in otherwise pristine lakes where atmospheric deposition of $\mathrm{Hg}$ and other constituents have been linked with elevated $\mathrm{Hg}$ levels in fish and subsequent fish consumption advisories (Sorensen and others, 1990). The Mercury Deposition Network (MDN) was established in 1995 as part of the National Atmospheric Deposition Program to provide a database of $\mathrm{Hg}$ concentrations in precipitation and $\mathrm{Hg}$ loading data from sites across the United States and Canada (additional information found at http://nadp.sws.uiuc.edu/mdn/). The purpose of the network as presented on the MDN website is to "develop information on spatial and seasonal trends in $\mathrm{Hg}$ deposited to surface waters, forested watersheds, and other sensitive receptors." Spatial comparison of MDN results shows the greatest yearly wet deposition of $\mathrm{Hg}$ occurring in the southeastern United States, especially along the Gulf of Mexico, and lower deposition to the north and west (Figure 1a). Volume-weighted $\mathrm{Hg}$ concentrations for precipitation are the highest in the arid and semi-arid Western States, in the Plains States, and in Florida (Figure 1b). Results from the MDN identify a poor spatial correlation between large $\mathrm{Hg}$ source areas (e.g., the Ohio Valley and the Tennessee Valley) and areas of elevated $\mathrm{Hg}$ deposition (e.g., the Gulf Coast region). To better understand sources of $\mathrm{Hg}$ found in wet deposition, some studies (including this one) have used a multi-element approach (Dvonch and others, 1998; Dvonch and others, 1999). Source determination of Hg measured in deposition may help provide a better understanding of apparent spatial disconnect between $\mathrm{Hg}$ sources and deposition.

In the autumn of 2002, the U.S. Geological Survey (USGS) Eastern Energy Resources Team, in cooperation with researchers at the George Mason University Department of Chemistry, installed and began operating an MDN site near Culpeper, Virginia (Site VA-08; Figure 2) with two primary purposes: 1) documenting $\mathrm{Hg}$ deposition in the region prior to implementation of planned Environmental Protection Agency (EPA) limits on $\mathrm{Hg}$ emissions from combustion sources; and 2) helping to fill a gap in the MDN that existed in the mid-Atlantic region (Figure 2). The station operated continuously from November of 2002 to the end of December of 2006. The sampler was modified in November of 2004 to collect samples for trace metal analysis concurrently with MDN Hg samples. Sampling was terminated at the end of December of 2006. Mercury deposition network site VA-28, located $31 \mathrm{~km}$ west at Big Meadows in Shenandoah National Park and operated by the National Park Service (Figure 2), was also installed in the autumn of 2002. The Big Meadows MDN site provides additional $\mathrm{Hg}$ data for the area, but is located a higher elevation (163 m at VA-08 and 1,074 $\mathrm{m}$ at VA-28). The VA-28 site is currently operating, together with three additional sites in the region added in 2004 (Figure 2). The purpose of this report is to summarize findings from the Culpeper MDN site, using results for weekly precipitation, from the initiation of the site in November of 2002 to the end of 2006, and compare these results with those for the Big Meadows MDN Site. Results from the Culpeper MDN site will also be used to constrain potential sources of $\mathrm{Hg}$ and other trace elements measured in precipitation samples at the Culpeper site.

\section{Potential Sources of Mercury in Atmospheric Wet Deposition}

Major potential source areas for $\mathrm{Hg}$ and other trace elements to the Culpeper and Big Meadows MDN sites include industrial facilities in and around Richmond, Virginia; Washington, D.C.; and Baltimore, Maryland, to the east and the industrial areas in the Midwestern States to the west. Several coal-fired power plants, a known source of $\mathrm{Hg}$, are also located around within 200 
$\mathrm{km}$ of the site (Figure 2). Coal-fired power plants are the largest point-source emitters of atmospheric $\mathrm{Hg}$ in the Commonwealth of Virginia (60.1\%; Table 1). Other important $\mathrm{Hg}$ sources include byproduct $\mathrm{Hg}$ emissions from metal production, specifically steel works and iron foundries (31.7\%), and $\mathrm{Hg}$ released during paper production (6.0\%), where it is used as a slimicide.

Emissions from coal-fired power plants are thought to be especially important because of the high proportion of reactive gaseous mercury (RGM) species, which are thought to be ionic forms of $\mathrm{Hg}$ bound to ligands (e.g., $\mathrm{HgCl}_{2(\mathrm{~g})}$ ), measured in some stack emissions (EPA, 1999). Conventional understanding regarding the behavior of atmospheric $\mathrm{Hg}$ species suggests that RGM species should be deposited quickly, on a local or regional scale (Lindberg and Stratton, 1998). This is in contrast to elemental $\mathrm{Hg}$, the dominant form $(\sim 95 \%)$ of $\mathrm{Hg}$ in the atmosphere, which has a lifetime of weeks to months and particulate $\mathrm{Hg}$, which varies greatly in solubility and residence time based on the composition and size of the particles. Therefore, where MDN sites are located in proximity to coal-fired power plants, coal combustion thought to be a significant source of $\mathrm{Hg}$ in precipitation at those sites (Keeler and others, 2006).

\section{Mechanisms for Trace Element Scavenging in Precipitation}

Two primary processes lead to the uptake of trace elements in precipitation: nucleation and trace gas scavenging (Walcek, 2003). Of these, nucleation scavenging, the transfer of chemical constituents from cloud condensation nuclei into cloud droplets as they form, is generally the primary source of trace elements in precipitation. Trace gas scavenging, the dissolution of soluble gases in cloud water, can also be an important process for addition of trace constituents to cloud water. Other mechanisms such as diffusion or impaction of gases and aerosols by precipitation drops (e.g. gas scavenging/impaction) can also occur, but are generally less efficient (Walcek, 2003).

With respect to wet deposition of $\mathrm{Hg}$, highly soluble RGM species and particulate-bound $\mathrm{Hg}$ are the most likely atmospheric $\mathrm{Hg}$ species involved in nucleation scavenging and gas scavenging reactions relative to elemental $\mathrm{Hg}$ (Lindberg and Stratton, 1998; Keeler and others, 1995). Therefore RGM and particulate $\mathrm{Hg}$ likely represent the most important species for uptake in precipitation and input via $\mathrm{Hg}$ wet deposition. Other trace elements, except selenium, do not typically occur in the gaseous state and are likely limited to uptake in the particulate form by nucleation scavenging, particle impaction or diffusion into cloud or precipitation droplets.

\section{Methods}

Standardized procedures for $\mathrm{Hg}$ sampling are required for participation in the MDN. Weekly precipitation samples for $\mathrm{Hg}$ analysis were collected in an ultra-clean acid-bearing glass bottle attached to a glass funnel and air lock (i.e., the sampling train) in a temperature-controlled modified Aerochem Metrics* sampler. A motorized lid controlled by a precipitation sensor prevented contamination of the samples during non-precipitation periods. Cumulative weekly precipitation at the site was recorded using a Belfort rain gauge, which also records the opening of the sampler lid. In late November of 2004 the precipitation collector was modified to accept a second sampling train used to collect precipitation samples for trace elements in precipitation other than $\mathrm{Hg}$ (herein referred to as trace elements). The trace element sampling train, consisted of a precleaned polyethylene funnel attached to a 1 liter HDPE sample bottle.

\footnotetext{
${ }^{*}$ Any use of trade, product, or firm names is for descriptive purposes only and does not imply endorsement by the U.S. Government.
} 
Samples for $\mathrm{Hg}$ and trace metals were collected weekly and sample trains were replaced using standard MDN protocols and clean sampling techniques (Olson and DeWild, 1999). Precleaned glass bottles and funnels for collection of samples for $\mathrm{Hg}$ analysis were provided by the MDN program. Polyethylene funnels for trace metal sampling were cleaned with a chelating soap bath, a $10 \%$ trace metal grade $\mathrm{HNO}_{3}$ acid bath, and rinsed in $18.2 \mathrm{~m} \% \mathrm{~cm}$ water. New polyethylene bottles were rinsed with $18.2 \mathrm{~m} / \mathrm{cm}$ water and $\sim 1 \%$ trace metal grade HNO3 acid. These trace element analyses followed a total digestion of samples in the original sample bottles (Hoffman and others, 1996). Samples were submitted to a commercial laboratory (Frontier Geosciences) for total $\mathrm{Hg}$ analysis by CVAFS and to the USGS Energy Program Laboratories in Denver, Colorado for trace element analysis via ICP-MS.

Method detection limits (MDLs) for individual trace elements were calculated using three times the standard deviation from blank $18.2 \mathrm{~m} \Omega / \mathrm{cm}$ water samples. All data were blank corrected. Field blanks produced similar analytical results to the blank $18.2 \mathrm{~m} \Omega / \mathrm{cm}$ water samples, suggesting that no significant contamination to the samples occurred from exposure to sampling conditions. To ensure proper analytical results, blind trace element reference materials (USGS TM standards T177, T-178) were periodically submitted for analytical results. For the elements used for this study, average errors between the reference materials and the analytical results range from $0.3 \%$ to $30 \%$, except for $\mathrm{Sb}(82 \%)$. To ensure continuity of results between the five separate batches of trace element samples from the study, statistical (Wilcoxon rank sum test) and graphical (boxplots) methods were applied to provide an intercomparison of analytical results for each element batch. Owing to a universal positive bias in almost all of the samples from the first two batches (collected from November, 2004, to July, 2005), data from these samples were eliminated from interpretation. In addition, elements in which $\geq 50 \%$ of the samples were below method detection limits were discarded from further use in the study. Elements in which $26 \%-49 \%$ of the samples were below detection limits $(\mathrm{Gd}, \mathrm{Nd}, \mathrm{Pb}, \mathrm{Sb})$ were only used for estimating summary statistics. The remaining trace elements (Al, Ca, Cd, Ce, Co, K, La, Mg, Mn, Na, Ni, Rb, Sr, V, Zn) and $\mathrm{Hg}$ contain enough data for reliable statistical testing and are the focus of this paper.

Owing to the presence of elemental concentrations below the MDL in some samples, nonparametric summary statistics (median and pseudo-• [interquartile range/1.349]) were estimated using a Kaplan-Meier cumulative proportion-based method. This method provides more reliable results for data sets containing samples below the MDL than substituting a constant value, such as 0.5 times the MDL, to those samples (Helsel, 2005). Monthly and annual wet deposition of each element was calculated by summing the product of corresponding weekly elemental concentration and total precipitation for a given time periods.

To identify potential source categories that contribute trace elements to precipitation samples, enrichment factor calculations and principal component analysis (PCA) were used. Enrichment factors were calculated via:

$$
\frac{\frac{X_{\text {sample }}}{A l_{\text {sample }}}}{\frac{X_{\text {cruast }}}{A l_{\text {crust }}}},
$$

where $\mathrm{X}_{\text {sample }}$ is the concentration of element $\mathrm{X}$ in a given sample, $\mathrm{Al}_{\text {sample }}$ is the concentration of aluminum in that same sample, Xcrust is the concentration of that same element in average crustal abundance (using data from Mason and Moore, 1982) and $\mathrm{Al}_{\text {crust }}$ is the concentration of aluminum in average crustal abundance (Duce and others, 1975). Following Shapiro-Wilks normality tests and quantile-quantile plots, all of the trace element data were log natural transformed and the $\mathrm{Hg}$ data 
were $\log$ base 10 transformed to satisfy requirements of PCA. A robust PCA method with varimax rotation was applied to the data, and an eigenvalue of 1 was used as a cutoff to determine the number of components to keep in the model. The PCA model presented in this study was found to show little influence in the structure and number of principal components as a result of removing individual elements from the analysis, suggesting the results are robust. All statistical analyses were completed using Numerical Cruncher Statistical System software (Hintze, 2005). Statistical significance is considered at $\mathrm{p}<0.05$ for all tests.

To determine potential source areas for air masses that produced specific precipitation events at the Culpeper MDN Site, 48-hour backward air mass trajectories were calculated using NOAA's HYbrid Single-Particle Lagrangian Integrated Trajectory (HYSPLIT) model (Draxler and Rolph, 2003). The HYSPLIT model uses a gridded meteorological dataset (EDAS 40km grid input dataset) containing wind components, temperature, height above ground surface, and surface pressure to calculate 3-D air parcel trajectories and is commonly used to investigate source areas of atmospheric contaminants (Cohen, 2004). To determine which source areas produced high loadings for each of the specific principal components (e.g., source categories) five weekly precipitation samples from the Culpeper MDN site with the largest factor scores for each principal component were identified. HYSPLIT modeling was applied for each individual precipitation event that contributed to significant precipitation accumulation in each of these weekly precipitation samples. To examine the robustness of the model and to investigate vertical variability in the model, trajectories were calculated for these events with initial heights of $100 \mathrm{~m}$, $250 \mathrm{~m}$, and $500 \mathrm{~m}$ above ground surface. Modeling result robustness was tested by comparing calculated trajectories from the HYSPLIT model for scenarios for 2-4 hours prior to and after the precipitation event, with those predicted for the precipitation event.

\section{Results and Discussion}

Quarterly and yearly volume-averaged $\mathrm{Hg}$ concentrations, precipitation, and $\mathrm{Hg}$ deposition for the Culpeper MDN site are provided in Table 2 (analysis excludes data for samples $<25 \mathrm{~mL}$, which are generally less reliable). The annual volume-averaged $\mathrm{Hg}$ concentrations of 6.7-8.6 ng/L and $\mathrm{Hg}$ deposition of $6.5-12.6 \mu \mathrm{g} / \mathrm{m}^{2}$ are comparable with measurements from other sites in the mid-Atlantic region (Figure 1). Mercury concentration at the Culpeper MDN site is generally highest during the second and third quarters of the year (Figure 3 and Table 2), except in 2004 and 2006 when the highest concentrations were observed during the first quarter. Precipitation is also generally greatest during the spring and summer leading to higher deposition during this period (Figure 4; discussed below). A seasonal variation in $\mathrm{Hg}$ concentration with a maximum in the summer months and a minimum in the winter months is observed at other MDN sites in the Eastern United States (Gay and others, 2006). This pattern has been attributed to higher concentrations of particulate $\mathrm{Hg}$ and RGM in the atmosphere during the spring and summer when the temperature is higher and actinic flux is greater, and thus photochemical oxidation reactions which form these oxidized $\mathrm{Hg}$ species are thought to be more active (Banic and others, 2005). As discussed in the Introduction, these species are more easily sequestered in precipitation than the more abundant elemental $\mathrm{Hg}$ species. The data also exhibit a statistically significant negative correlation between weekly total precipitation and $\mathrm{Hg}$ concentrations, suggesting a dilution effect during larger precipitation events, often referred to as "rain-out" (Figure 5). This effect is more pronounced in the winter relative to autumn and summer and may reflect a smaller, more rapidly depleted pool of available $\mathrm{Hg}$ during the colder months. A strong dilution effect was also noticed in the springtime, but resulted from elevated $\mathrm{Hg}$ concentrations during small events $(<20 \mathrm{~mm})$ rather than a stronger drop off during larger events $(>50 \mathrm{~mm})$. This "rain-out" effect is highlighted by anomalously low 
$\mathrm{Hg}$ precipitation concentrations measured at several mid-Atlantic MDN sites (e.g., $3.4 \mathrm{ng} / \mathrm{L}$ at Culpeper and $2.7 \mathrm{ng} / \mathrm{L}$ at Big Meadows MDN sites) receiving significant precipitation during Hurricane Isabel (samples taken the week ending September 22, 2003) as shown in Figure 6 and discussed by Kolker and others (2004).

Plots of weekly and cumulative $\mathrm{Hg}$ deposition for 2003-2006 (Figures 4,6) show that highest $\mathrm{Hg}$ deposition (up to $5.0 \mu \mathrm{g} / \mathrm{m}^{2}$ per quarter of the $6.5-12.6 \mu \mathrm{g} / \mathrm{m}^{2}$ annual $\mathrm{Hg}$ deposition) is measured during the second and third quarters of the year (April-September). The 2003 annual $\mathrm{Hg}$ deposition of $12.6 \mu \mathrm{g} / \mathrm{m}^{2}$ is much larger than for 2004,2005 , and $2006\left(7.8,8.8\right.$, and $6.5 \mu \mathrm{g} / \mathrm{m}^{2}$, respectively) and is a function of both higher $\mathrm{Hg}$ concentration and increased precipitation over that calendar year. A marked increase $\left(2.1 \mu \mathrm{g} / \mathrm{m}^{2}\right)$ in cumulative deposition is also noted in two weekly samples from September 2003, prior to Hurricane Isabel (denoted by gray rectangle in Figure 6). During this period, the site received $>140 \mathrm{~mm}$ of precipitation and $\mathrm{Hg}$ concentrations were elevated (weekly $\mathrm{Hg}$ concentrations of 12.9 and $26.6 \mathrm{ng} / \mathrm{L}$ ). HYSPLIT backward trajectory modeling of trajectories corresponding to individual rain events during this period of high deposition indicate that the air masses in the boundary layer at the Culpeper MDN site during these storms originated from the Ohio Valley and traveled east at low elevations $(<1,000 \mathrm{~m})$. Two other periods of greater than $0.8 \mu \mathrm{g} / \mathrm{m}^{2}$ deposition were measured in July of 2005 (Figure 4). HYSPLIT modeling of trajectories for individual rain events during these periods identified the Ohio and Tennessee Valleys as likely source areas. Industrial sources in regions identified as source areas by the HYSPLIT model likely contributed to the elevated $\mathrm{Hg}$ observed during these periods. A second potential source for $\mathrm{Hg}$ in precipitation during these larger events may be scavenging of high concentrations of RGM from the free troposphere during convective storms (Guentzel and others, 2001).

\section{Comparison with the Big Meadows Mercury Deposition Network Site}

Quarterly and annual data from 2002 to 2006 site for the Big Meadows MDN site (VA-28) are provided in Table 3. Seasonal variation in wet $\mathrm{Hg}$ deposition for the Big Meadows MDN site is similar to data for the Culpeper MDN site, with higher deposition measured from April to September (quarters 2 and 3) relative to quarters 1 and 4, as a result of greater precipitation and elevated $\mathrm{Hg}$ concentrations in precipitation during those periods. Results from a paired Wilcoxon signed rank test indicate that quarterly $\mathrm{Hg}$ deposition is not significantly different between the two sites (See Figure 7). However quarterly volume-averaged $\mathrm{Hg}$ concentrations at Culpeper are significantly greater than for the Big Meadows site (Figure 8), while quarterly total precipitation is higher at the Big Meadows site $(\mathrm{p}<0.05)$. This relationship suggests that lower $\mathrm{Hg}$ concentrations at the Big Meadows site relative to the Culpeper site are likely a result of additional $\mathrm{Hg}$ dilution during larger precipitation events. Similar Hg deposition at the two sites suggests both sites are exposed to a similar $\mathrm{Hg}$ burden from wet deposition and that $\mathrm{Hg}$ deposition at the two sites is dominated by regional or larger-scale sources and depositional processes, rather than local sources.

\section{Trace Element Results and Interpretation}

Trace element samples were collected for 70 weeks of sampling representing the period from July, 2005 to December, 2006 and were determined for 57 different trace elements. Results for 58 of the samples are presented here; the remaining 12 samples were collected from weeks with $<1 \mathrm{~mm}$ precipitation and eliminated from further analyses. The trace element data were used to identify trace element (including $\mathrm{Hg}$ ) source categories being deposited at the Culpeper MDN site. With the exception of $\mathrm{Hg}$ ( $\log$ base 10 normally distributed), all of the other elements were $\log$ 
normally distributed and were natural log-transformed. Summary statistics for each element are provided in Table 4 and monthly average volume-weighted concentrations and deposition for selected elements are shown in Figure 9.

Median trace element concentrations ranged from $1.4 \mathrm{ng} / \mathrm{L}$ for $\mathrm{Gd}$ to $190 \pm 280 \mu \mathrm{g} / \mathrm{L}$ for Ca (Table 4). Volume-weighted concentrations were typically greater for most elements during the summer months, although lower precipitation rates $(<50 \mathrm{~mm} / \mathrm{month})$ during these periods produced little response in monthly deposition (Figure 9). Several of the elements exhibited both high volume-weighted concentrations and monthly deposition in October of 2005, primarily responding to elevated trace element concentrations during a storm that deposited $90 \mathrm{~mm}$ of rain on October $5^{\text {th }}$ and $6^{\text {th }}$. HYSPLIT trajectory modeling of this precipitation event identify areas to the east and northeast (e.g., the Washington, D.C.-Baltimore, Maryland region and further south) as likely source areas (Figure 2). Other than this anomaly in October, most elements showed only moderate variation in monthly deposition during the study period except for high wintertime deposition of $\mathrm{V}$ in 2005 and high springtime deposition of $\mathrm{Zn}, \mathrm{Hg}$, and $\mathrm{Mn}$.

Trace element wet deposition for the Culpeper MDN site was calculated for 2006, the only year with a complete set of trace element data, and is provided in Table 4. For comparison, trace element wet deposition data (Al, Zn, Mn, V, Ni, Pb, and Cd) for Reston, Virginia from 1998 are provided (Conko and others, 2004). Reston is a suburban town (pop. 60,000) located roughly 100 $\mathrm{km}$ northeast of the VA-08 site and $20 \mathrm{~km}$ northwest of Washington, D.C. (Figure 2). Although the data from Culpeper and Reston data were collected from different years, both aluminum deposition ( $70 \mathrm{mg} / \mathrm{m} 2 / \mathrm{yr}$ vs. $52 \mathrm{mg} / \mathrm{m} 2 / \mathrm{yr}$, respectively) and total annual precipitation $(969 \mathrm{~mm}$ and $919 \mathrm{~mm}$, respectively) are similar between data sets suggesting that similar results would be observed for other trace elements if both sites had similar source inputs. Despite these similarities, annual deposition of $\mathrm{Cd}, \mathrm{Zn}, \mathrm{Ni}, \mathrm{Mn}$, and V (in order of decreasing difference) were $10 \%$ to $340 \%$ higher for Reston than for the Culpeper MDN site. These results suggest that the suburban Reston site may be more impacted by local sources of these elements than the more rural Culpeper site.

Enrichment factor calculations for precipitation samples from the Culpeper MDN site indicate that only $\mathrm{Hg}, \mathrm{Cd}$, and $\mathrm{Zn}$ greatly exceed (i.e., $\mathrm{EF}>10$ ) crustal abundances (Figure 10), suggesting these elements are dominated by input from anthropogenic sources (Duce and others, 1975). Potential sources of $\mathrm{Cd}$ and $\mathrm{Zn}$ in regional wet deposition include vehicle related particles $(\mathrm{Zn})$, coal-fired power plants $(\mathrm{Cd})$, and non-ferrous metal smelting (Cd and $\mathrm{Zn}$; Lucey and others, 2001, Conko and others, 2004). The latter two source categories are also dominant sources of anthropogenic $\mathrm{Hg}$ in Virginia (Table 1). Spearman rank-based correlation between the three elements range from 0.43 to 0.60 suggesting that $\mathrm{Hg}, \mathrm{Cd}$, and $\mathrm{Zn}$ may be derived from similar sources or source areas, although $\mathrm{Hg}$ concentrations are more strongly correlated with $\mathrm{Mn}$ $(\rho=0.66)$, Co $(\rho=0.61)$, and K $(\rho=0.60)$. Several other elements exhibited EF values (1-10) that are moderately enriched relative to crustal averages (i.e., $\mathrm{Ca}, \mathrm{Na}, \mathrm{V}, \mathrm{Ni}, \mathrm{Sr}, \mathrm{Mg}, \mathrm{Mn}$, and $\mathrm{K}$ ) suggesting input from both natural and anthropogenic sources and/or local variation in crustal emission factors relative to a global crustal average.

To better identify the potential source categories of the trace elements determined in precipitation samples at the Culpeper MDN site, principal component analysis was applied. The analysis identified three principal components, which accounted for roughly $76 \%$ of the variance in the data (Table 5). The first principal component is dominated by strong factor loadings $(>0.7)$ of $\mathrm{Ca}, \mathrm{Al}, \mathrm{Mg}, \mathrm{Sr}, \mathrm{La}$, and $\mathrm{Ce}$ (Figure 11). This component is interpreted as input from crustal sources, which agrees with the low EF values $(<10)$ calculated for these elements (Figure 10). Other than the high loading in October, 2005 (discussed previously) only minimal variation in wet deposition of elements associated with this component are observed (Figure 9). This suggests a near constant source strength and is consistent with a crustal source for this principal component. 
Backward air mass trajectory calculations corresponding to precipitation events associated with the 5 samples with the highest factor loadings for this principal component were extremely varied and trended from almost every direction. This variability is consistent with a ubiquitous source such as continentally derived dust.

Strong factor loadings of $\mathrm{V}$ with moderate loadings of $\mathrm{Na}$ and $\mathrm{Ni}$ in the second principal component (Figure 11) likely represent input from oil combustion; for which $\mathrm{V}$ and $\mathrm{Ni}$ are well known tracers and are both highly enriched in oil (Khalaf and others, 1982; Nriagu and Pacyna, 1988). This finding agrees with the interpretation of the $\mathrm{EF}$ values for $\mathrm{V}$ and $\mathrm{Ni}(4.3+/-8.3$ and 3.9 $+/$-5.6) which suggest that average crustal input only contributes $\sim 25 \%$ of these elements. Oil combustion is used as a source of electricity in Virginia, Maryland, Delaware, Pennsylvania and many other surrounding States and is also used as a source of residential heating, primarily during the winter months. Wet deposition rates of $\mathrm{V}$ during this study were markedly higher during the wintertime than other periods (Figure 9), suggesting that local residential heating was the primary source corresponding to this principal component. Nickel deposition at the Culpeper MDN site was similarly elevated in the wintertime but also peaked in the fall and summer, likely responding to input from other dominant Ni sources other than oil combustion (e.g., metal production).

HYSPLIT modeling results during precipitation events corresponding to the 5 samples with the highest factor loadings for this principal component suggest pathways to the north or west from Canada or from the southeast as likely trajectories. These trajectories further agree with our interpretation by suggesting colder meteorological conditions during which combustion of V-and Ni-bearing oil for heating would be most anticipated.

The final principal component exhibits strong factor loadings of $\mathrm{Zn}, \mathrm{Cd}, \mathrm{Mn}$, and $\mathrm{Hg}$ (Figure 11). As discussed above, three of these elements ( $\mathrm{Zn}, \mathrm{Cd}$, and $\mathrm{Hg}$ ) have the highest EF values and thus are the most likely to be dominated by anthropogenic inputs, but correlate with one another only moderately. Lack of strong correlation between the dominant elements suggests that this component may represent input from multiple sources or source areas, rather than a single source. Therefore, this principal component is interpreted to exhibit a response from a variety of regional anthropogenic emission sources such as metal production $(\mathrm{Mn}, \mathrm{Cd}, \mathrm{Zn}$, and $\mathrm{Hg}$ ), vehicle related particles (Zn), and coal-fired power plants (Cd and $\mathrm{Hg}$; Pacyna and Pacyna, 2001).

Backward air mass trajectories, as determined by HYSPLIT, for precipitation events corresponding to the five samples with the largest factor scores suggest that the Ohio Valley (e.g., West Virginia, Ohio, Kentucky, and Indiana) and the northeastern U.S. coast (New Jersey to Vermont) are the primary source areas for this component (Figure 12).

To estimate the input of these three principal components on $\mathrm{Hg}$ deposition at the Culpeper MDN site, they were regressed against the weekly $\mathrm{Hg}$ concentrations. The analysis indicated that the three components accounted for $\sim 60 \%$ of the variability of $\mathrm{Hg}$ concentrations in wet deposition. The third component (mixed anthropogenic emission sources) accounted for roughly $51 \%$ of the input of $\mathrm{Hg}$ in wet deposition, while crustal sources (first principal component) and local oil combustion (second principal component) contributed only $9.5 \%$ and $<1 \%$, respectively. The remaining $40 \%$ of input may be attributed to the global atmospheric burden. These findings should be taken with caution because they represent a fairly short duration (July, 2005 to December, 2006) and the samples were collected on a weekly timescale and likely include input from multiple sources and precipitation events.

\section{Summary}

Findings from this study suggest that $\mathrm{Hg}$ measured in precipitation at the Culpeper MDN site (and the Big Meadows MDN site) is derived from multiple sources on a regional or larger scale 
rather than local sources. The highest concentrations and deposition of $\mathrm{Hg}$ at these sites are measured in the spring and summer. The high $\mathrm{Hg}$ loading during these periods are a result of increased precipitation and possibly elevated levels of more soluble ionic $\mathrm{Hg}$ species. Combination of the $\mathrm{Hg}$ results with concentration data for other trace elements allowed for a better understanding of the likely sources of $\mathrm{Hg}$ input to the Culpeper MDN site. Preliminary analysis suggests that anthropogenic emission sources such as coal-fired power plants and metal refineries contribute roughly $51 \%$ of the $\mathrm{Hg}$ input, while crustal sources and local oil combustion contribute significantly less $(9.5 \%$ and $<1 \%$ respectively). For comparison Keeler and others (2006) attributed $\sim 70 \%$ of the $\mathrm{Hg}$ in wet deposition at Steubenville, Ohio to coal combustion sources alone.

Further examination of data from wet mercury deposition sites located closer to more urbanized areas such as Beltsville, Maryland (MD-99; Figure 2) and heavily industrialized areas such as Steubenville, Ohio (Keeler and others, 2006) exhibit higher deposition rates (12.0-19.7 $\left(\mathrm{g} / \mathrm{m}^{2} / \mathrm{yr}\right)$ than more remote sites such as the Culpeper and Big Meadows MDN sites. Drop-off in wet $\mathrm{Hg}$ deposition with distance can be explained by: 1) significant deposition and depletion of $\mathrm{Hg}$ in the immediate vicinity of the utility plants owing to the high proportion of RGM emitted from coal-fired power plants and 2) post-emission conversion of RGM species to less reactive, elemental $\mathrm{Hg}$ (Edgerton and others, 2006), which may be transported over long distances, for weeks or months, before being deposited (Lindberg and Stratton, 1998). Therefore, deposition at more remote sites is intrinsically more impacted by deposition from the global $\mathrm{Hg}$ burden (up to $40 \%$ of the $\mathrm{Hg}$ deposited at the Culpeper MDN site) than for sites near large $\mathrm{Hg}$ emission sources.

Significant long-term changes in $\mathrm{Hg}$ deposition at the site may require reduction of regional $\mathrm{Hg}$ emission, such as those currently prescribed by the EPA Clean Air Mercury Rule (more information at http://www.epa.gov/oar/mercuryrule/), as well as global reductions from other large international anthropogenic source areas such as eastern Asia and Europe. It is noteworthy that these initial findings examine only $\mathrm{Hg}$ in wet deposition. Assessing and measuring dry deposition is significantly more complicated, but would provide stakeholders with a better understanding of the total atmospheric $\mathrm{Hg}$ burden. For this reason further, ongoing USGS atmospheric $\mathrm{Hg}$ research emphasizes both wet and dry deposition. Additional collection of baseline and monitoring results, such as those presented here, will allow for continued assessment on the future impacts of $\mathrm{Hg}$ emissions.

\section{Acknowledgments}

The authors would like to recognize the USGS Energy Program for providing funding for the project. Analysis of the precipitation samples for trace elements was conducted at the USGS Energy Labs in Denver, Colorado. This manuscript was greatly improved by comments from Robert Ayuso (USGS - Reston, Virginia) and James Shanley (USGS - Montpelier, Vermont).

\section{References}

Banic, C., Blanchard, P., Dastoor, A., Hung, H., Steffen, A., Tordon, R., Poissant, L., and Wiens, B., 2005, Atmospheric distribution and long-range transport of mercury, chap. 9 of Mineralogical Association of Canada Short Course 34, Halifax, Nova Scotia, Canada, May 14-15, 2005 : 
Parsons, M.B., Percival, J.B., eds., Mercury - Sources, Measurements, Cycles, and Effects, p. 157-177.

Cohen, M., Artz, R., Draxler, R., Miller, P., Poissant, L., Niemi, D., Ratté, D., Deslauriers, M., Duval, R., Laurin, R., Slotnick, J., Netteshein, T., and McDonald, J., Modeling the atmospheric transport and deposition of mercury to the Great Lakes: Environmental Research, v. 95, p. 247265.

Draxler, R.R., and Rolph, G.D., 2003, HYSPLIT (HYbrid Single-Particle Lagrangian Integrated Trajectory) Model access via NOAA ARL READY Website

(http://www.arl.noaa.gov/ready/hysplit4.html): NOAA Air Resources Laboratory, Silver Spring, Maryland.

Duce, R.A., Hoffman, G.L., and Zoller, W.H., 1975, Atmospheric trace metals at remote northern and southern hemisphere sites: Pollution or Natural?: Nature, v. 187, p. 59-61.

Dvonch, J.T., Graney, J.R., Marsik, F.J., Keller, G.J., and Stevens, R.K., 1998, An investigation of source-receptor relationships for mercury in south Florida using event precipitation data: The Science of the Total Environment, v. 213, p. 95-108.

Dvonch, J.T., Graney, J.R., Keeler, G.J., and Stevens, R.K., 1999, Use of elemental tracers to source apportion mercury in south Florida precipitation: Environmental Science and Technology, v. 33, p. 4522-4527.

Edgerton, E.S., Hartsell, B.E., and Jansen, J.J., 2006, Mercury speciation in coal-fired power plant plumes observed at three surface sites in the southeastern U.S.: Environmental Science and Technology, v. 40, p. 4563-4570.

Gay, D., Prestbo, E., Brunette, R., and Sweet, C., 2006, Wet deposition of mercury in the U.S. and Canada, 1996-2004: Results, trends, and future directions of the NADP mercury deposition network (MDN) [abs.]: $8^{\text {th }}$ International Conference on Mercury as a Global Pollutant Abstracts, T-208, p. 242.

Guentzel, J.L., Landing, W.M., Gill, G.A., and Pollman, C.D., 2001, Processes influencing rainfall deposition of mercury in Florida: Environmental Science and Technology, v. 35, p. 863-873.

Helsel, D.R., 2005, Nondetects and data analysis: Statistics for censored environmental data: New York, N.Y., John Wiley and Sons, 250 p.

Hintze, J. L., 2005, NCSS Statistical Systems User's Guide: Number Cruncher Statistical Systems, Kaysville, Utah.

Hoffman, G.L., Fishman, M.J., and Garbarino, J.R., 1996, Methods of analysis by the U.S.

Geological Survey National Water Quality Laboratory - In-bottle acid digestion of whole-water samples: U.S. Geological Survey Open-File Report 96-225, 28 p.

Keeler, G., Landis, M.S., Norris, G.A., Christianson, E.M., and Dvonch, J.T., 2006, Sources of mercury wet deposition in Eastern Ohio, USA: Environmental Science \& Technology, v. 40, p. 5874-5881.

Keeler, G., Glinsorn, G., and Pirrone, N., 1995, Particulate mercury in the atmosphere: Its significance, transport, transformation and sources: Water, Air, and Soil Pollution, v. 80, p. 159168.

Khalaf, F.; Literathy, V., and Anderlini, V., 1982, Vanadium as a tracer of oil pollution in the sediments of Kuwait: Hydrobiolgia, v. 91-92, p. 147-154.

Kolker, A., Mose, D.G., and Spitzer, S., 2004, Filling a gap: MDN station VA-08 (Culpeper) and VA-28 (Shenandoah National Park - Big Meadows) in Virginia [abs.]: National Atmospheric Deposition Program (NADP), 2004 Scientific Symposium, Halifax, Nova Scotia, Canada.

Lindberg, S.E., and Stratton, W.J., 1998, Atmospheric mercury speciation: Concentrations and behavior of reactive gaseous mercury in ambient air: Environmental Science and Technology, v. 32, p. 49-57. 
Lucey, D., Hadliiski, L., Hopke, P.K., Scudlark, J.R., and Church, T., 2001, Identification of sources of pollutants in precipitation measured at the mid-Atlantic US coast using potential source contribution function (PSCF): Atmospheric Environment, v. 35, p. 3979-3986.

Mason, B., and Moore, C.B., 1982, Principles of Geochemistry ( $4^{\text {th }}$ ed.): New York, N.Y., Wiley, $344 \mathrm{p}$.

Nriagu, J.O., and Pacyna, J.M., 1988, Quantitative assessment of worldwide contamination of air, water and soils by trace metals: Nature, v. 333, 134-139.

Olson, M.L., and DeWild, J.F., 1999, Low-level collection techniques and species-specific analytical methods for mercury in water, sediment, and biota: U.S. Geological Survey WaterResources Investigation Report 01-466, 14p.

Pacyna, J.M, and Pacyna, E.G., 2001, An assessment of global and regional emissions of trace metals to the atmosphere from anthropogenic sources worldwide: Environmental Reviews, v. 9, p. 269-298.

Sorensen, J.A., Glass, G.E., Schmidt, K.W., Huber, J.K., and Rapp, G.R., Jr., 1990, Airborne mercury deposition and watershed characteristics in relation to mercury concentrations in water, sediments, plankton, and fish in eighty Northern Minnesota Lakes: Environmental Science and Technology, v. 24, p. 1716-1727.

U.S. EPA, 1999, Information Collection Request: found at http://www.epa.gov/ttn/atw/combust/utiltox/mercury.html.

Walcek, C., 2003, Fate of atmospheric trace gases: Wet deposition, chap. 19 of Potter, T.D., Colman, B.R., eds., Handbook of Weather, Climate, and Water: Atmospheric Chemistry, Hydrology, and Societal Impacts: John Wiley \& Sons, Inc., p.357-371. 


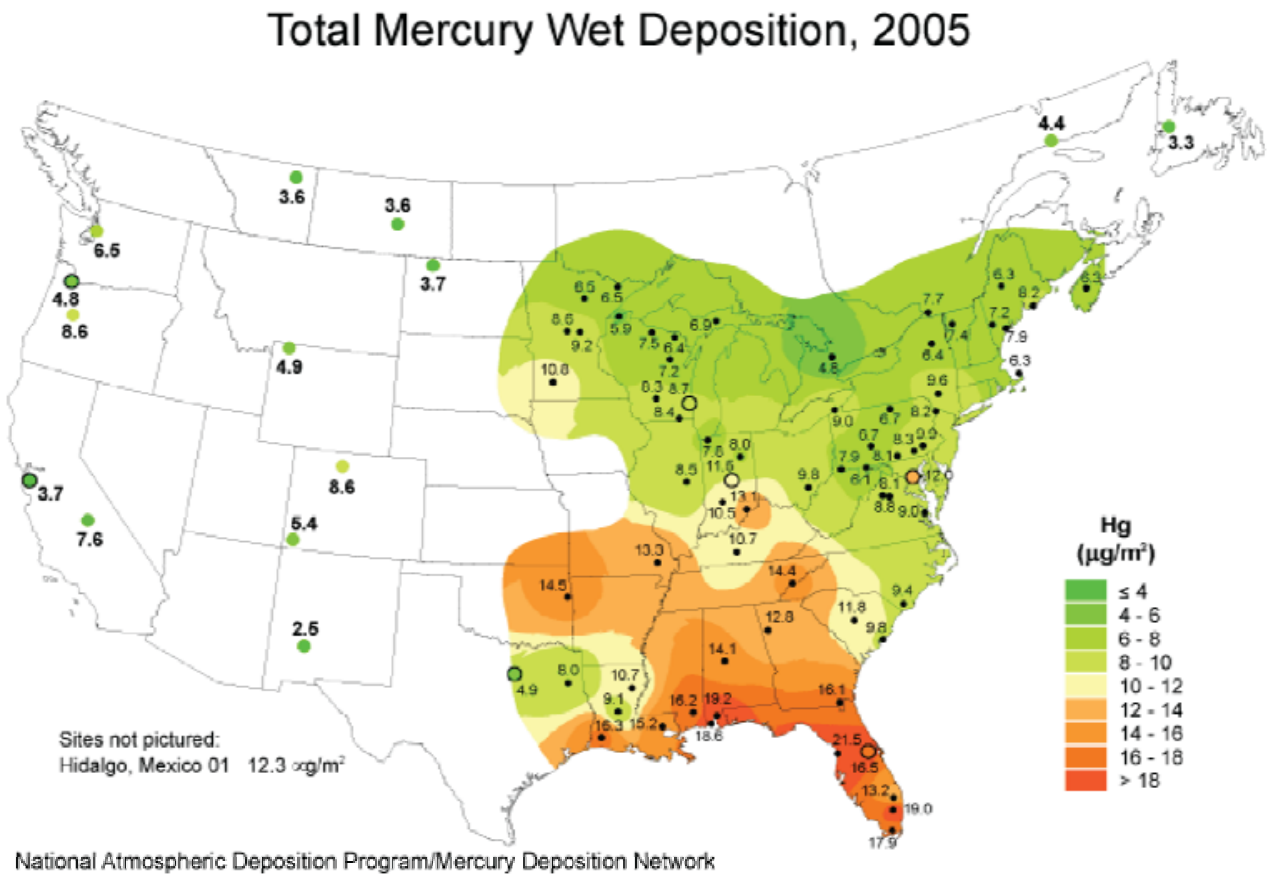

Total Mercury Concentration, 2005

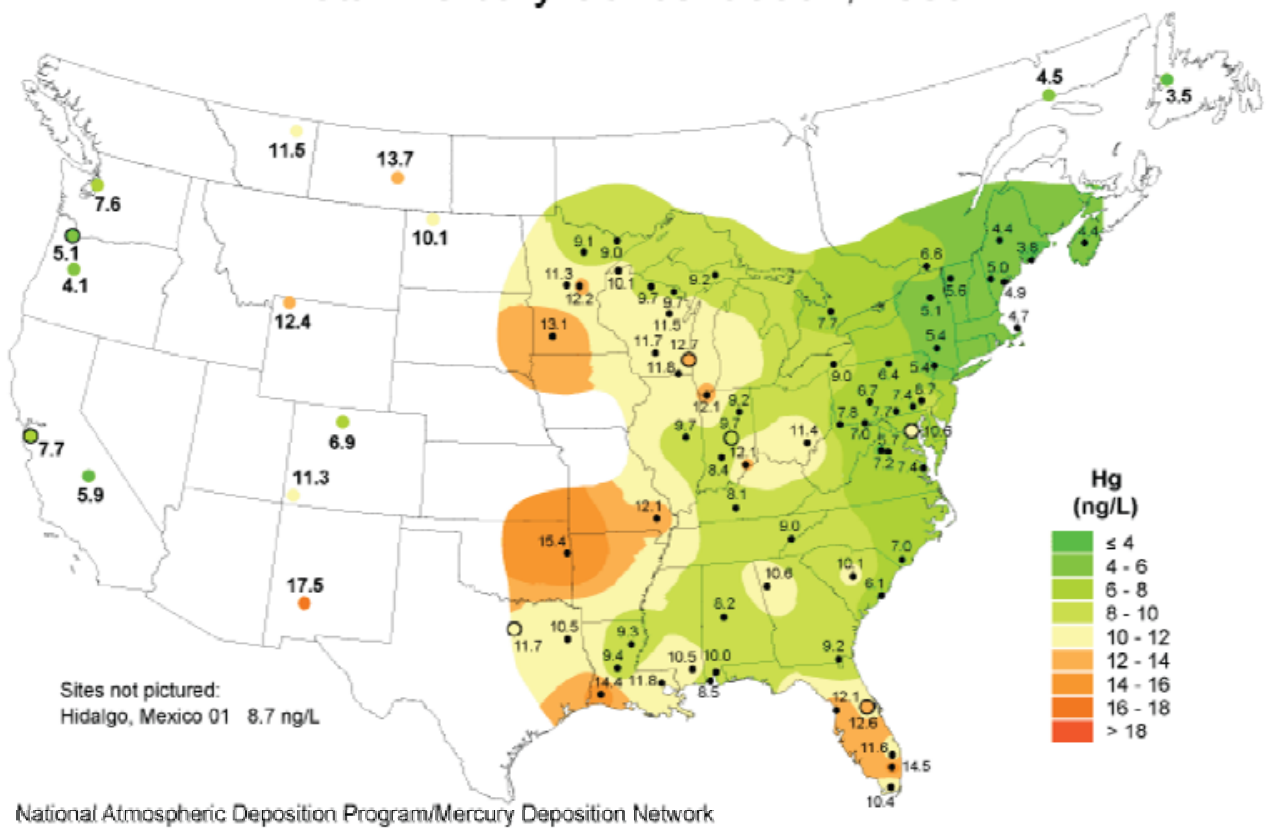

Figure 1. Contoured 2005 annual wet deposition (1a; upper figure) and volume-weighted average precipitation ( $1 \mathrm{~b}$; lower figure) for Mercury Deposition Network sites. Maps available from the Mercury Deposition Network website (http://nadp.sws.uiuc.edu/mdn/). 


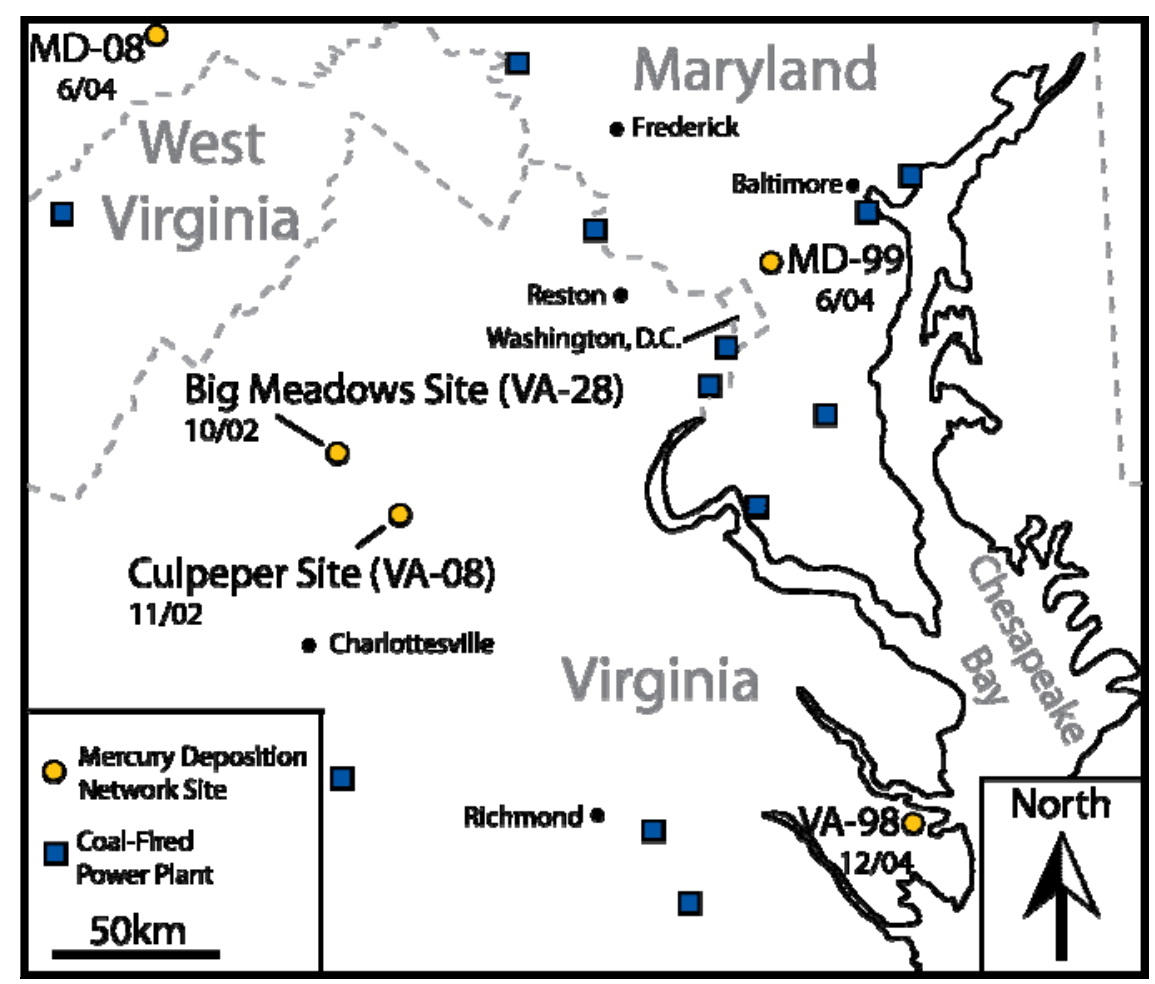

Figure 2. Map showing the location of the Culpeper (VA-08), Big Meadows (VA-28), and surrounding Mercury Deposition Network sites and coal-fired power plant locations. Dates listed below the MDN site names indicate start dates. The figure shows that no regional MDN sites existed prior to the installation of the VA-08 and VA-28 sites in 2002. 

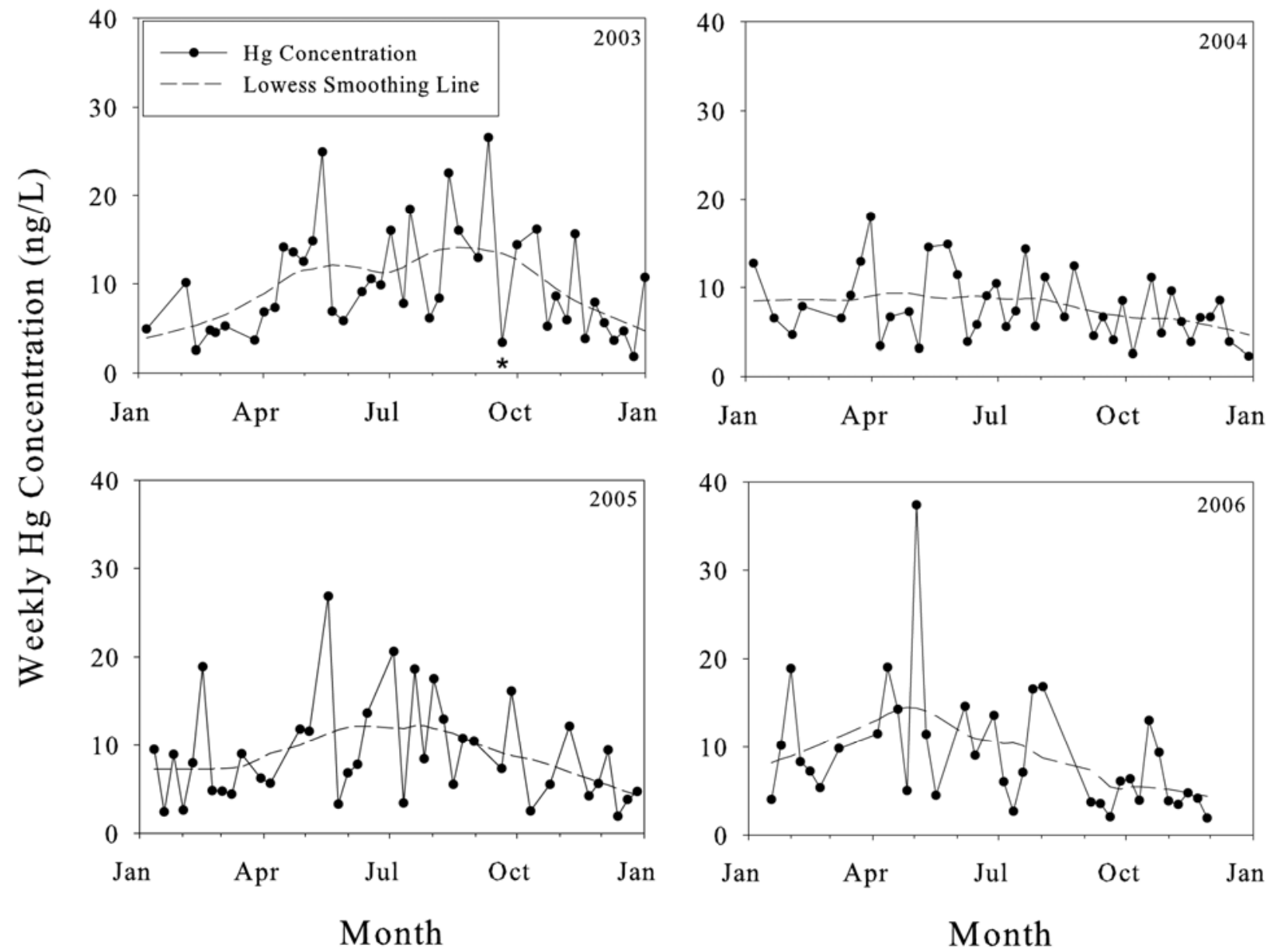

Figure 3. Weekly $\mathrm{Hg}$ concentrations in precipitation for 2003-2005 with lowess smoothing line ( $\mathrm{f}=0.4)$ showing overall trend in results with peak concentration. This figure highlights the trend of higher $\mathrm{Hg}$ concentrations during the spring and summer, except in 2004 when first quarter concentrations were the highest. An asterisk denotes weekly sample during which Hurricane Isabelle occurred. 

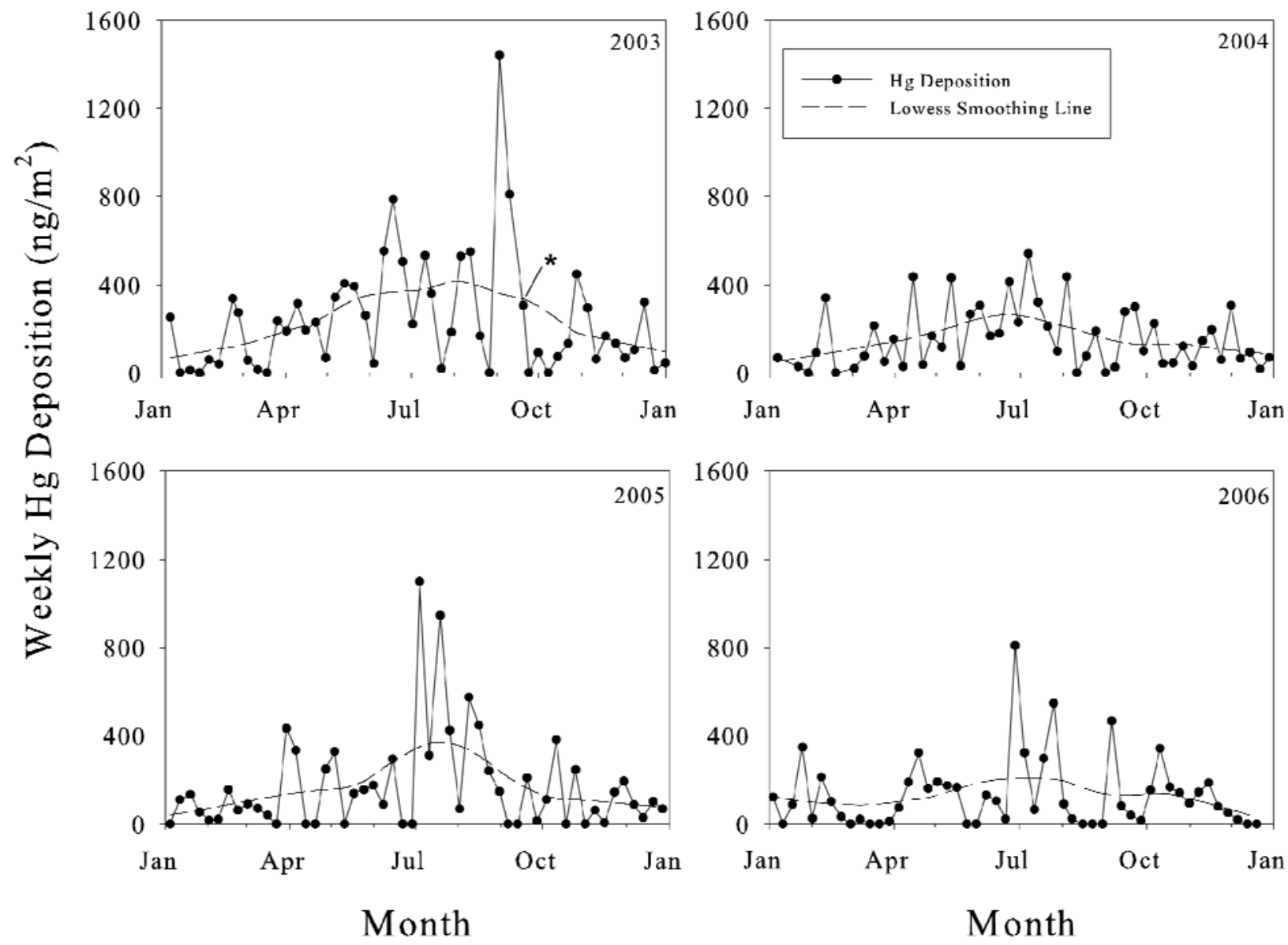

Figure 4. Weekly wet $\mathrm{Hg}$ deposition for 2003-2005 with lowess smoothing line $(f=0.4)$ showing overall trend in results with peak concentration. This figure highlights the trend of higher $\mathrm{Hg}$ deposition during late spring and summer. An asterisk denotes weekly sample during which Hurricane Isabelle occurred. 

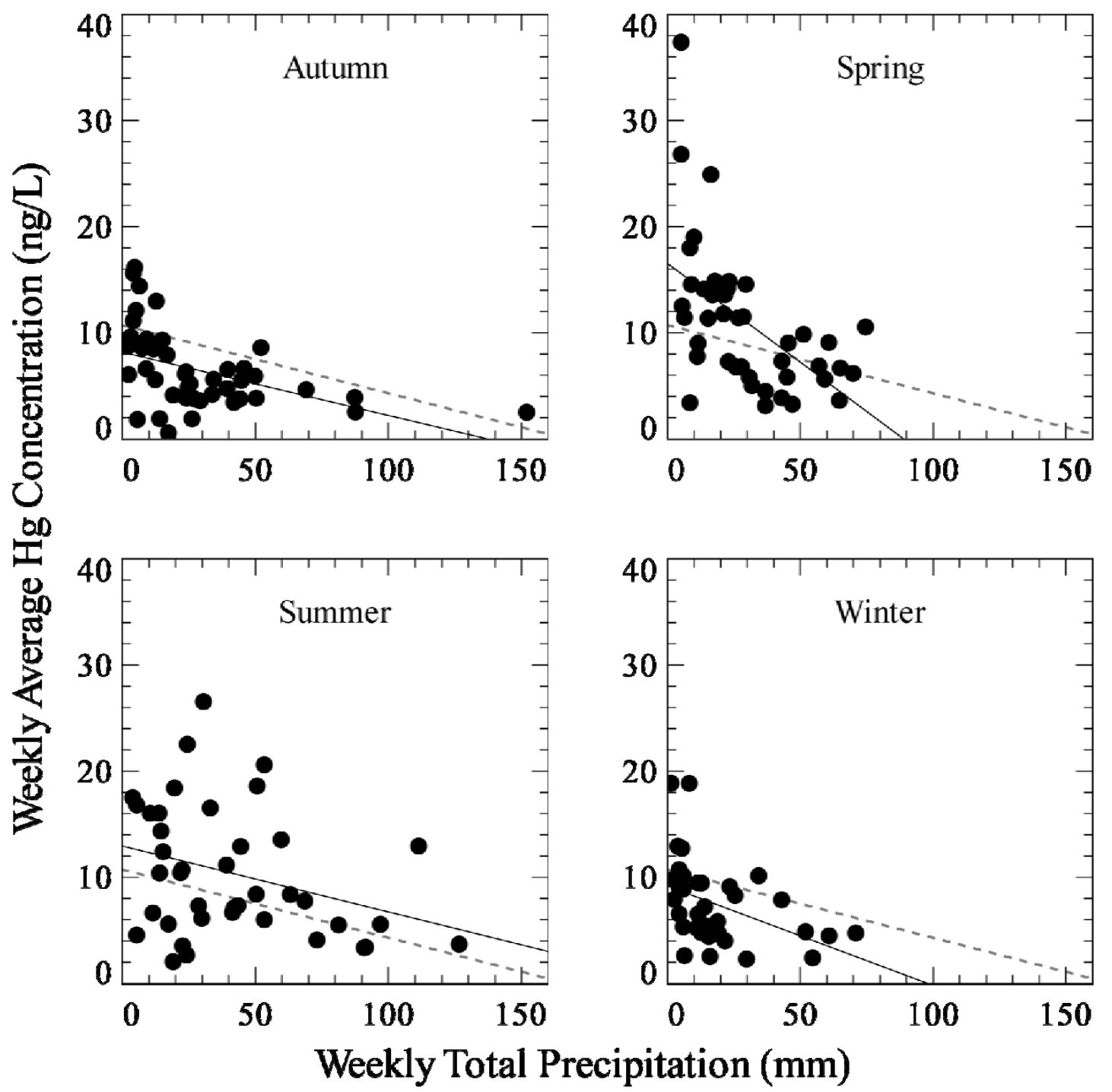

Figure 5. Plot of weekly $\mathrm{Hg}$ concentration and weekly total precipitation of 2002-2005 data. Ordinary least squares regression shown by trend line $(r 2=0.07, p<0.05)$. This plot illustrates an overall decrease in $\mathrm{Hg}$ concentration with increasing weekly precipitation. 


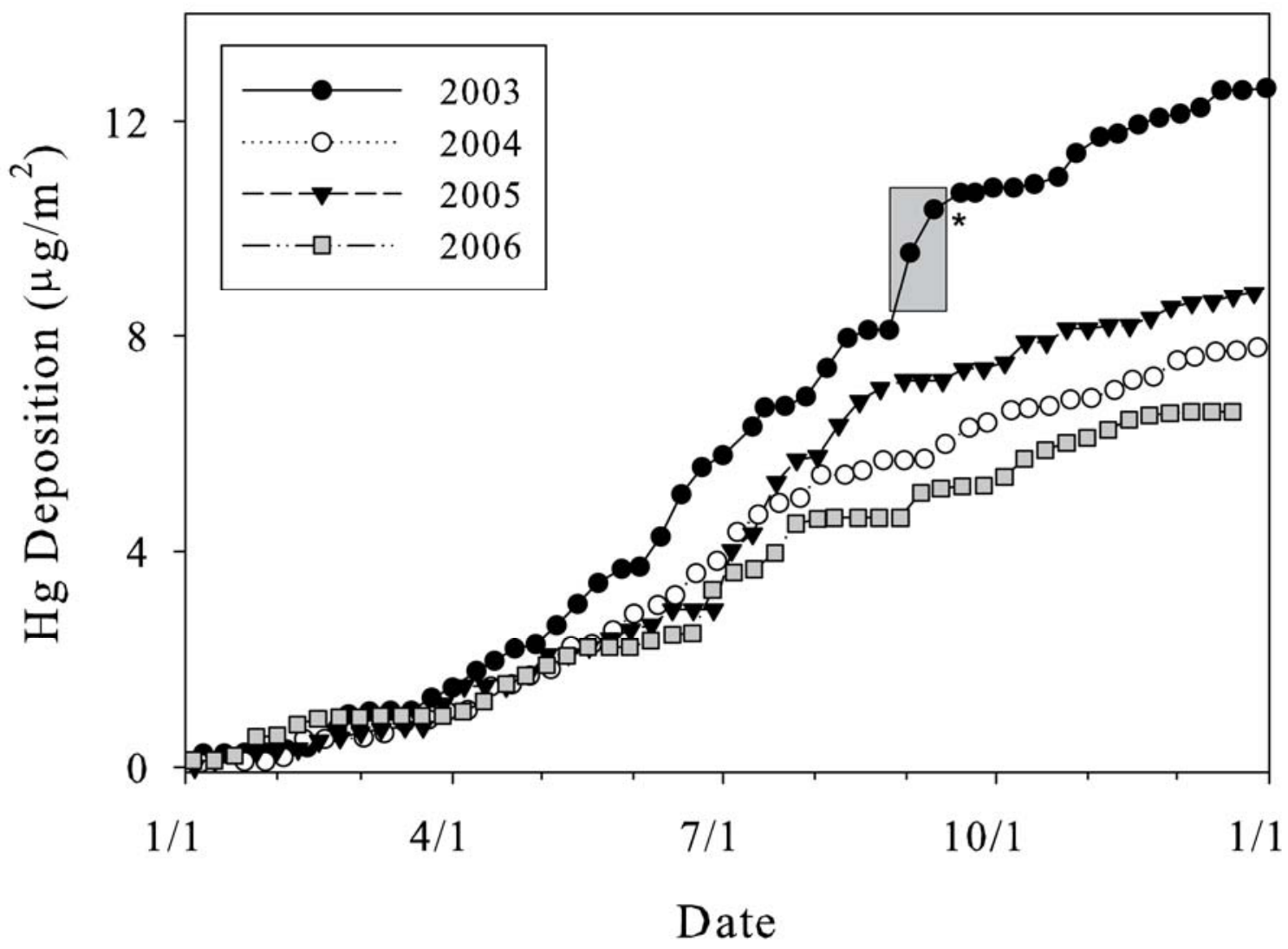

Figure 6. Cumulative $\mathrm{Hg}$ deposition for the years 2003-2005. Gray box outlines a period of anomalously large deposition. Data plotted in this figure highlight the higher deposition during the spring and summer quarters. An asterisk denotes weekly sample during which Hurricane Isabelle occurred. 


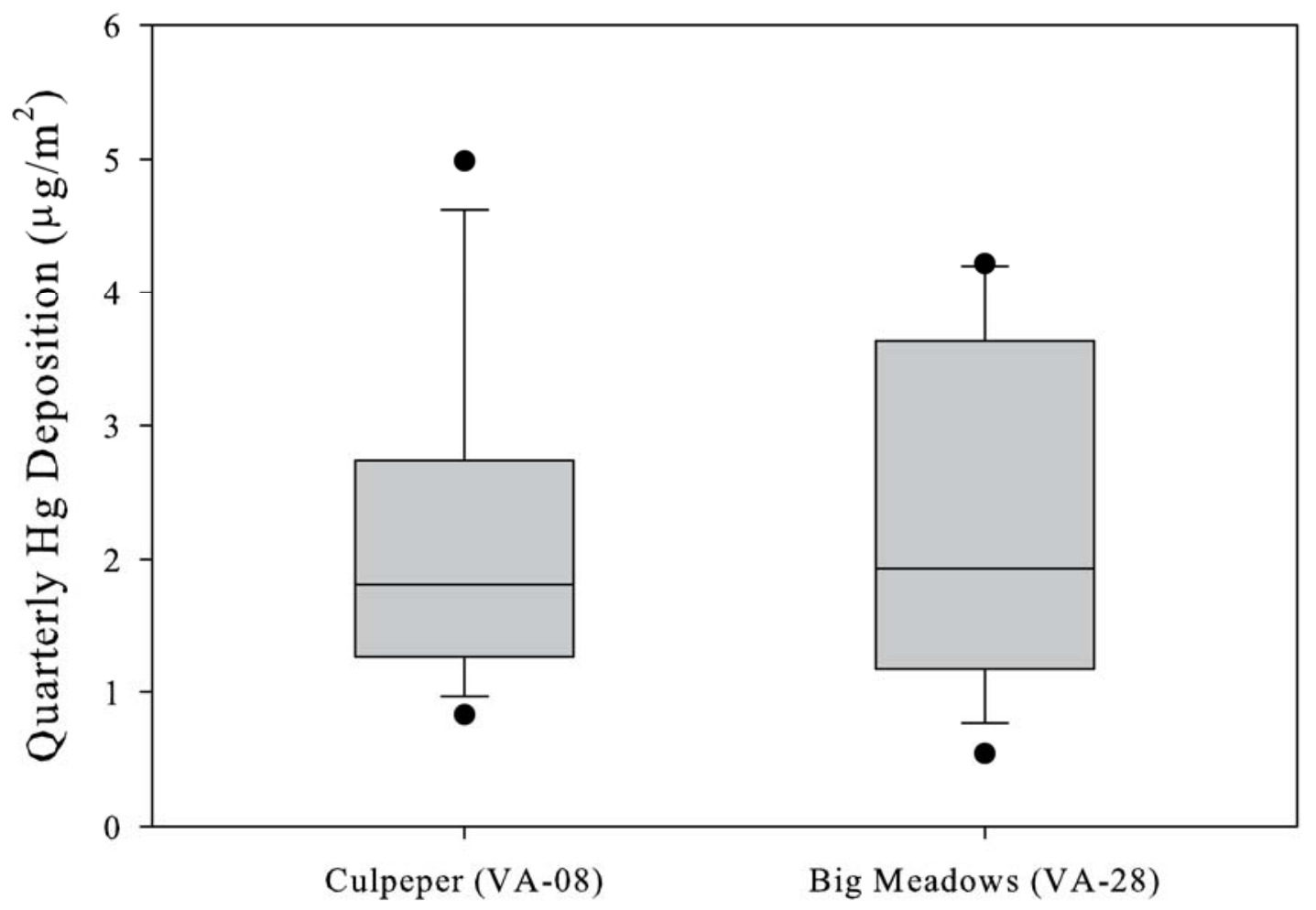

Figure 7. Boxplots comparing quarterly $\mathrm{Hg}$ deposition at the Culpeper and Big Meadows MDN sites for the 16 quarters from January 2003 to December 2006. This plot shows similar deposition between the two sites. 


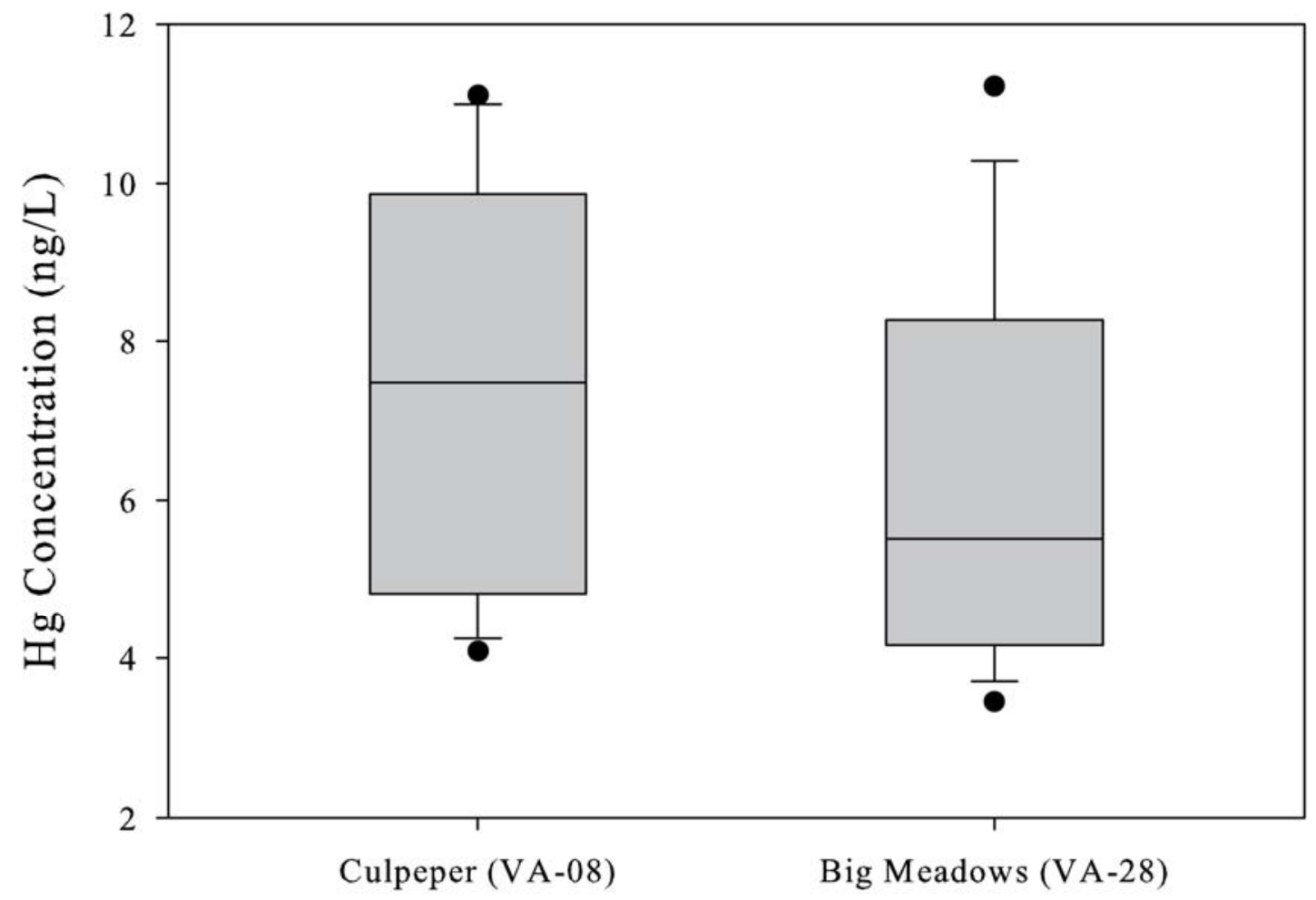

Figure 8. Boxplots comparing quarterly volume-averaged $\mathrm{Hg}$ concentration at the Culpeper and Big Meadows MDN sites for the 16 quarters from January 2003 to December 2006. This plot illustrates higher $\mathrm{Hg}$ concentrations at the Culpeper MDN site. 

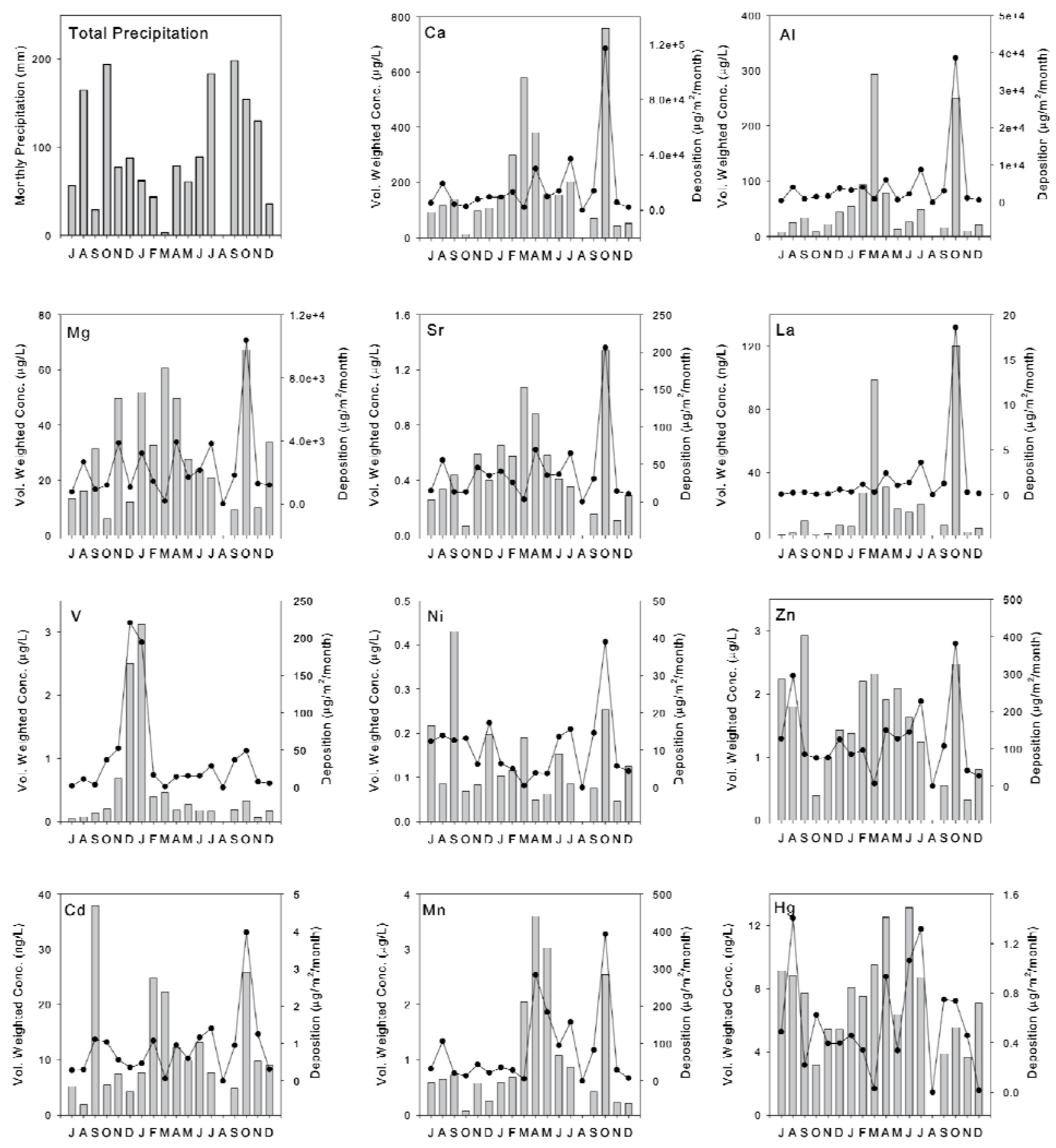

Figure 9. Monthly volume-weighted concentration and wet deposition for selected trace elements at the Culpeper MDN site from July 2005 to December 2006. This plot shows temporal variability of key trace elements during the study period. 


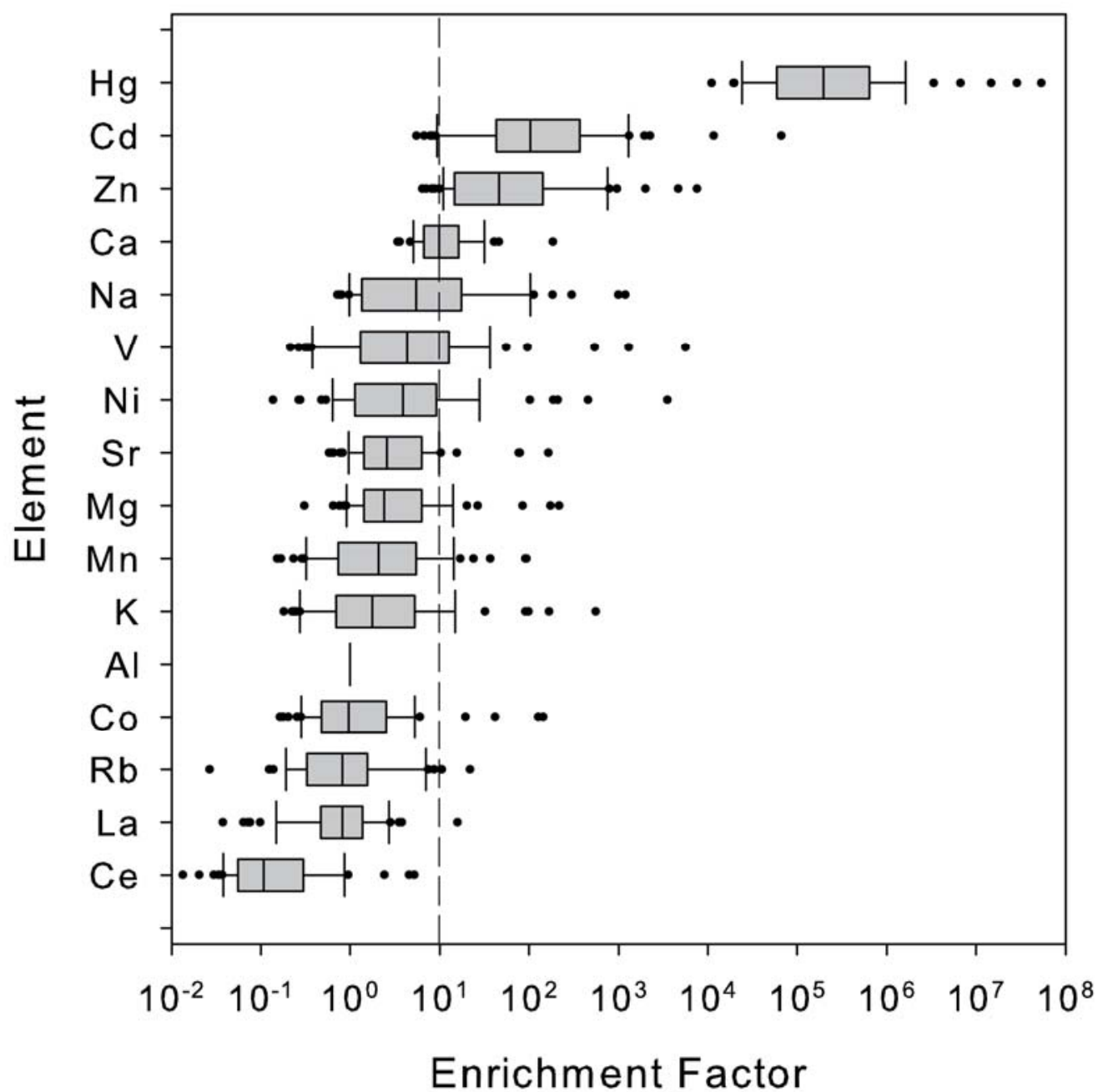

Figure 10. Boxplots showing the variability of enrichment factors normalized to aluminum for trace elements in Culpeper MDN precipitation samples. Elements with enrichment factors $>10$ are considered highly enriched and those from 1-10 are moderately enriched relative to average crustal abundance. 

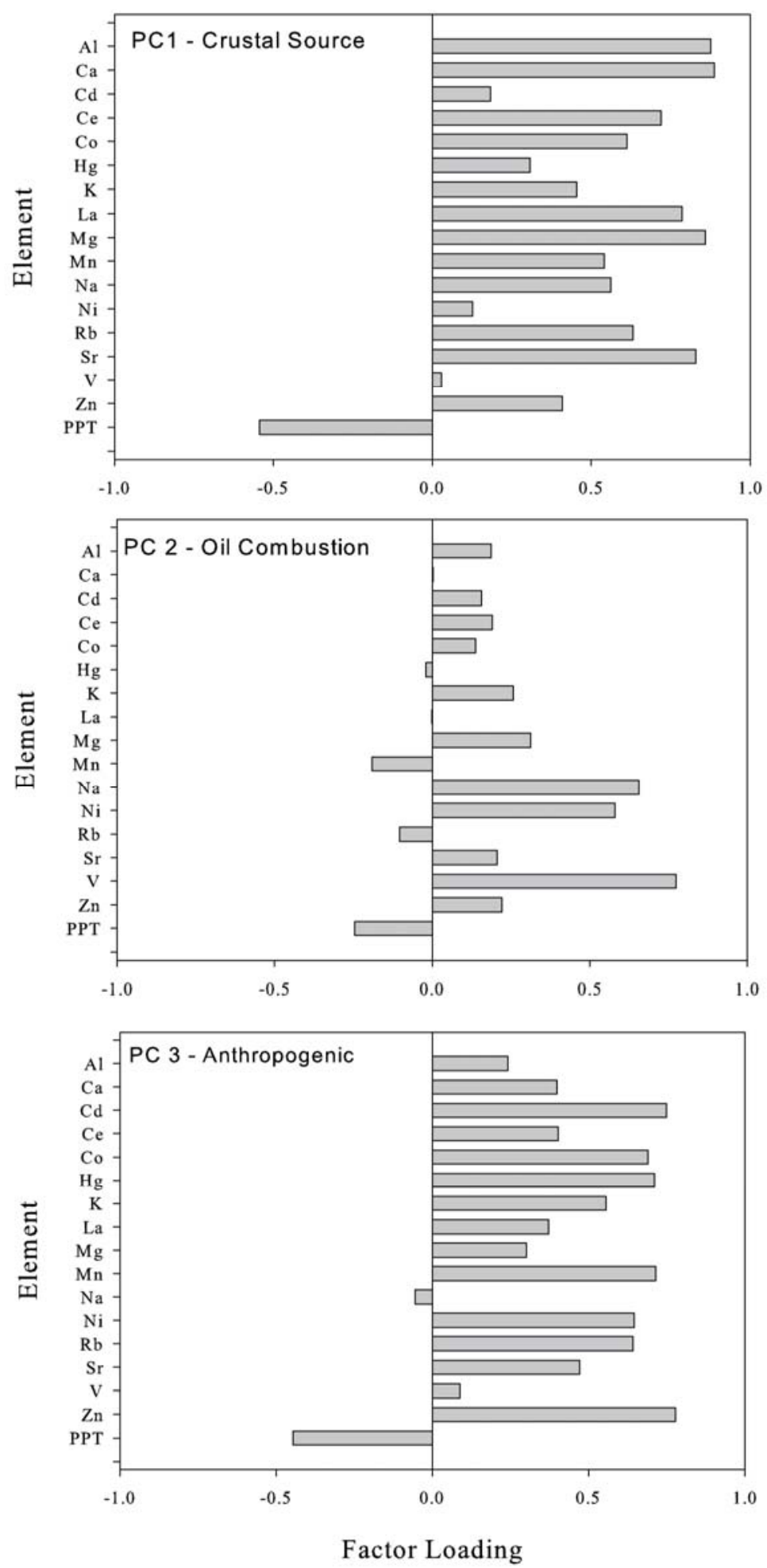

Figure 11. Element factor loadings for each of the three principal components (PC) generated from principal component analysis. Larger magnitude (positive or negative) factor loadings indicate a stronger relationship between a given element and that principal component. 


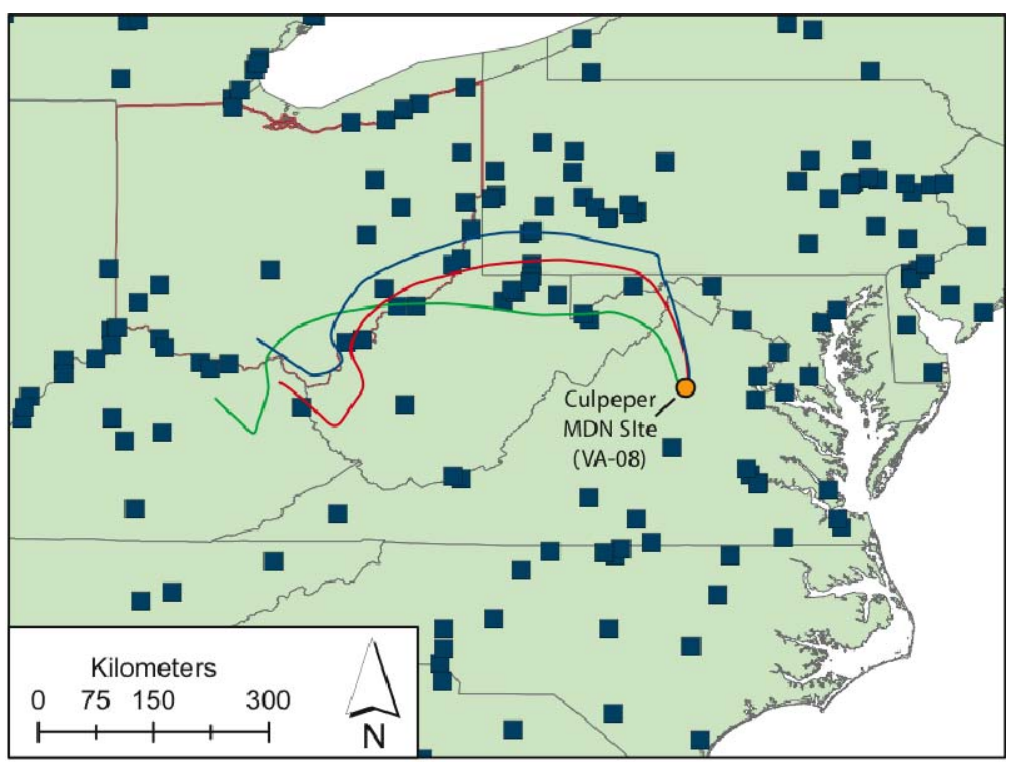
$\sim 100 \mathrm{~m}$ Trajectory
$\frown 500 \mathrm{~m}$ Trajectory
$\curvearrowright 250 \mathrm{~m}$ Trajectory
- Coal-Fired Power Plant

Figure 12. Backward air mass trajectories at $100 \mathrm{~m}, 250 \mathrm{~m}$, and $500 \mathrm{~m}$, for an event starting at 4 PM ( $20 \mathrm{Z}$ hour) on May 5, 2006. This plot demonstrates that air masses which produced a precipitation event at the Culpeper MDN site on this date and time were previously transported across the Ohio Valley and possibly intercepted emissions from coal-fired power plants and other anthropogenic sources. 
Table 1. Point-source mercury emissions for the Commonwealth of Virginia for 2005. Data taken from the EPA Toxic Release Inventory (accessible via www.epa.gov/triexplorer).

\begin{tabular}{lcc}
\multicolumn{1}{c}{ Source } & Emissions (kg) & Percent of Total \\
\hline Electric Utilities & 560 & $60.1 \%$ \\
Primary Metals Production & 295 & $31.7 \%$ \\
Paper Production & 56 & $6.0 \%$ \\
Cement Production & 6 & $0.7 \%$ \\
Petroleum Products & 6 & $0.7 \%$ \\
Ammunition Production & 4 & $0.4 \%$ \\
Tobacco Production & 4 & $0.4 \%$ \\
\hline
\end{tabular}

Total

931 
Table 2. Quarterly average $\mathrm{Hg}$ concentration, precipitation, and $\mathrm{Hg}$ deposition for the Culpeper MDN site (VA-08), 2002-2005.

\begin{tabular}{lccc} 
Period & $\begin{array}{c}\text { Avg. Hg Conc. } \\
(\mathbf{n g} / \mathbf{L})\end{array}$ & $\begin{array}{c}\text { Precipitation } \\
(\mathbf{m m})\end{array}$ & $\begin{array}{c}\text { Hg Deposition } \\
\left(\boldsymbol{\mu} \mathbf{g} / \mathbf{m}^{2}\right)\end{array}$ \\
\hline Q4 2002 & 5.7 & 92 & 0.5 \\
& & & \\
Q1 2003 & 4.6 & 312 & 1.5 \\
Q2 2003 & 10.3 & 423 & 4.3 \\
Q3 2003 & 10.9 & 456 & 5.0 \\
Q4 2003 & 6.2 & 318 & 1.9 \\
2003 Total & 8.6 & 1507 & 12.6 \\
& & & \\
Q1 2004 & 8.8 & 120 & 1.0 \\
Q2 2004 & 7.9 & 350 & 2.8 \\
Q3 2004 & 7.0 & 370 & 2.6 \\
Q4 2004 & 4.3 & 312 & 1.4 \\
2004 Total & 6.7 & 1152 & 7.8 \\
& & & \\
Q1 2005 & 5.3 & 210 & 1.2 \\
Q2 2005 & 7.9 & 219 & 1.8 \\
Q3 2005 & 10.2 & 441 & 4.5 \\
Q4 2005 & 4.1 & 333 & 1.5 \\
2005 Total & 7.2 & 1217 & 8.9 \\
& & & \\
Q1 2006 & 7.9 & 106 & 0.8 \\
Q2 2006 & 11.1 & 209 & 2.3 \\
Q3 2006 & 6.2 & 353 & 2.1 \\
Q4 2006 & 4.6 & 301 & 1.2 \\
2006 Total & 7.0 & 969 & 6.5 \\
' 210
\end{tabular}

${ }^{1}$ Volume-weighted average; only includes data for samples $>25 \mathrm{~mL}$

${ }^{2}$ Not an entire quarter of results (Nov. 19-Dec. 31) 
Table 3. Quarterly average $\mathrm{Hg}$ concentration, precipitation, and $\mathrm{Hg}$ deposition for the Big Meadows MDN site (VA-08), 2002-2005.

\begin{tabular}{lccc} 
Period & $\begin{array}{c}\text { Avg. Hg Conc. } \\
\text { (ng/L) }\end{array}$ & $\begin{array}{c}\text { Precipitation } \\
(\mathbf{m m})\end{array}$ & $\begin{array}{c}\text { Hg Deposition } \\
\left(\boldsymbol{\mu g} / \mathbf{m}^{2}\right)\end{array}$ \\
\hline Q4 2002 & 3.6 & 278 & 1.0 \\
& & & \\
Q1 2003 & 4.4 & 471 & 2.0 \\
Q2 2003 & 9.6 & 492 & 3.9 \\
Q3 2003 & 9.9 & 644 & 4.2 \\
Q4 2003 & 4.8 & 390 & 1.8 \\
2003 Total & 7.1 & 1997 & 11.9 \\
& & & \\
Q1 2004 & 4.9 & 193 & 0.9 \\
Q2 2004 & 8.4 & 379 & 3.2 \\
Q3 2004 & 5.5 & 779 & 4.2 \\
Q4 2004 & 3.8 & 314 & 1.2 \\
2004 Total & 5.8 & 1665 & 9.5 \\
& & & \\
Q1 2005 & 4.1 & 243 & 1.0 \\
Q2 2005 & 7.9 & 215 & 1.7 \\
Q3 2005 & 7.6 & 417 & 3.1 \\
Q4 2005 & 3.5 & 523 & 1.2 \\
2005 Total & 5.8 & 1398 & 7.0 \\
& & & \\
Q1 2006 & 5.5 & 188 & 0.5 \\
Q2 2006 & 11.2 & 337 & 3.8 \\
Q3 2006 & 5.8 & 501 & 2.8 \\
Q4 2006 & 3.9 & 484 & 1.9 \\
2006 Total & 6.4 & 1510 & 9.0 \\
& & & \\
${ }^{1}$ Volume-weighted average; only includes data for samples $>25 \mathrm{~mL}$ \\
\\
${ }^{2}$ Not an entire quarter of results (Oct. 22-Dec. 31) \\
\end{tabular}


Table 4. Summary statistics and total wet deposition of trace elements for the Culpeper, Virginia MDN site ( $n=59)$. Results reflect samples from July 2007-December 2006 for trace elements, November 2003-December $2006 \mathrm{for} \mathrm{Hg}$, and the 2006 calendar year for annual wet deposition estimates. Summary statistics estimated using Kaplan-Meier cumulative proportion-based methods for samples below method detection limits (Helsel, 2005). \%ND = Percentage of samples below method detection limit.

\begin{tabular}{|c|c|c|c|c|c|c|c|c|c|}
\hline Element & Min & Max & Median & psuedoo & $\%$ ND & Vol Weighted Avg. & $\begin{array}{l}\text { Conc. } \\
\text { Units }\end{array}$ & $\begin{array}{c}2006 \text { Total Dep. } \\
\left(\mu \mathrm{g} / \mathrm{m}^{2} / \mathrm{yr}\right)\end{array}$ & $\begin{array}{c}1998 \text { Reston Dep } \\
\left(\mu \mathrm{g} / \mathrm{m}^{2} / \mathrm{yr}\right)\end{array}$ \\
\hline $\mathrm{Ca}$ & $<1.6$ & 2000 & 190 & 280 & $5 \%$ & 183 & $\mu \mathrm{g} / \mathrm{L}$ & 250000 & -- \\
\hline $\mathrm{Na}$ & 8.9 & 3500 & 53 & 68 & $0 \%$ & 84.2 & $\mu \mathrm{g} / \mathrm{L}$ & 85000 & -- \\
\hline $\mathrm{Al}$ & $<0.09$ & 680 & 30 & 91 & $3 \%$ & 50.3 & $\mu \mathrm{g} / \mathrm{L}$ & 70000 & 52000 \\
\hline $\mathrm{Mg}$ & 2.8 & 430 & 29 & 33 & $0 \%$ & 25.2 & $\mu \mathrm{g} / \mathrm{L}$ & 31000 & -- \\
\hline $\mathrm{K}$ & $<1.7$ & 990 & 20 & 23 & $7 \%$ & 25.5 & $\mu \mathrm{g} / \mathrm{L}$ & 28000 & -- \\
\hline $\mathrm{Zn}$ & $<0.15$ & 52 & 1.5 & 1.2 & $2 \%$ & 1.33 & $\mu \mathrm{g} / \mathrm{L}$ & 1400 & 4100 \\
\hline $\mathrm{Mn}$ & $<0.006$ & 26 & 0.73 & 1.0 & $2 \%$ & 0.94 & $\mu \mathrm{g} / \mathrm{L}$ & 1300 & 2000 \\
\hline $\mathrm{Sr}$ & 0.032 & 5.4 & 0.45 & 0.62 & $0 \%$ & 0.43 & $\mu \mathrm{g} / \mathrm{L}$ & 540 & -- \\
\hline $\mathrm{V}$ & $<0.071$ & 5.4 & 0.18 & 0.22 & $20 \%$ & 0.43 & $\mu \mathrm{g} / \mathrm{L}$ & 390 & 430 \\
\hline $\mathrm{Ni}$ & $<0.017$ & 7.1 & 0.11 & 0.09 & $5 \%$ & 0.11 & $\mu \mathrm{g} / \mathrm{L}$ & 110 & 240 \\
\hline $\mathrm{Pb}$ & $<0.03$ & 1.9 & 0.08 & -- & $31 \%$ & -- & $\mu \mathrm{g} / \mathrm{L}$ & NA & 440 \\
\hline $\mathrm{Rb}$ & $<0.59$ & 1500 & 32 & 40 & $7 \%$ & 38 & $\mathrm{ng} / \mathrm{L}$ & 53 & -- \\
\hline $\mathrm{La}$ & $<0.52$ & 320 & 13 & 24 & $22 \%$ & 19 & $\mathrm{ng} / \mathrm{L}$ & 31 & -- \\
\hline $\mathrm{Co}$ & $<3.5$ & 180 & 11 & 16 & $17 \%$ & 10 & $\mathrm{ng} / \mathrm{L}$ & 14 & -- \\
\hline $\mathrm{Cd}$ & $<2.5$ & 750 & 8.6 & 13 & $25 \%$ & 9.7 & $\mathrm{ng} / \mathrm{L}$ & 12 & 54 \\
\hline $\mathrm{Hg}$ & 0.56 & 37 & 7.2 & 5.0 & $0 \%$ & 7.5 & $\mathrm{ng} / \mathrm{L}$ & 6.5 & -- \\
\hline $\mathrm{Ce}$ & $<0.30$ & 430 & 3.9 & -- & $25 \%$ & 5.7 & $\mathrm{ng} / \mathrm{L}$ & 5.2 & -- \\
\hline $\mathrm{Nd}$ & $<1.4$ & 230 & 2.3 & -- & $42 \%$ & -- & $\mathrm{ng} / \mathrm{L}$ & NA & -- \\
\hline $\mathrm{Sb}$ & $<0.70$ & 180 & 1.7 & 6.5 & $27 \%$ & -- & $\mathrm{ng} / \mathrm{L}$ & NA & -- \\
\hline $\mathrm{Gd}$ & $<0.09$ & 42 & 1.4 & -- & $36 \%$ & -- & $\mathrm{ng} / \mathrm{L}$ & NA & -- \\
\hline
\end{tabular}

${ }^{1}$ Based on $969 \mathrm{~mm}$ total precipitation.

${ }^{2}$ Wet deposition data for nearby Reston, Virginia from Conko et al.(2004). Based on $919 \mathrm{~mm}$ total precipitation. 
Table 5. Summary of results from principal component analysis on Culpeper MDN precipitation data. Elements listed exhibited $>0.5$ absolute factor loadings; those in bold > 0.7. (-) symbol indicates negative loading. PC $=$ Principal component. PPT $=$ precipitation.

PC

Ca, Al, Mg, Sr, La, Ce, Rb, Co, Na, PPT(-), Mn, K, Zn

$\mathrm{V}, \mathrm{Na}, \mathrm{Ni}$

Zn, Cd, Mn, Hg, Co, Ni, Rb, K, Sr, PPT(-), Ce
Eigenvalue

6.31

1.84

4.84
Individual \%

37

11

28

Cum. \%
37
48
76

Source

Crustal

Oil Combustion

Anthropogenic 